\title{
Tumor necrosis factor- $\alpha$ triggers opposing signals in head and neck squamous cell carcinoma and induces apoptosis via mitochondrial- and non-mitochondrial-dependent pathways
}

\author{
DENIS SELIMOVIC ${ }^{1}$, RENATE U. WAHL ${ }^{2}$, EMMANUELLE RUIZ $^{3}$, RIZWAN ASLAM ${ }^{4}$, THOMAS W. FLANAGAN ${ }^{5}$, \\ SOFIE-YASMIN HASSAN ${ }^{2}$, SIMEON SANTOURLIDIS ${ }^{6}$, YOUSSEF HAIKEL ${ }^{1,7}$, PAUL FRIEDLANDER ${ }^{4}$, \\ MOSAAD MEGAHED ${ }^{2}$, EMAD KANDIL ${ }^{3}$ and MOHAMED HASSAN ${ }^{1,3}$ \\ ${ }^{1}$ INSERM UMR 1121, University of Strasbourg, 67000 Strasbourg, France; ${ }^{2}$ Clinic of Dermatology, \\ University Hospital of Aachen, 52074 Aachen, Germany; Departments of ${ }^{3}$ Surgery and ${ }^{4}$ Otolaryngology, \\ Tulane University School of Medicine; ${ }^{5}$ Department of Pharmacology and Experimental Therapeutics, \\ LSU Health Sciences Center, New Orleans, LA 70112, USA; ${ }^{6}$ Epigenetics Core Laboratory, \\ Institute of Transplantation Diagnostics and Cell Therapeutics, University Hospital of Düsseldorf, \\ Heinrich-Heine-University of Düsseldorf, 40225 Düsseldorf, Germany; \\ ${ }^{7}$ Department of Operative Dentistry and Endodontics, Dental Faculty, \\ University of Strasbourg, 67000 Strasbourg, France
}

Received November 7, 2017; Accepted February 21, 2018

DOI: 10.3892/ijo.2019.4900

\begin{abstract}
Head and neck squamous cell carcinoma (HNSCC) remains one of the most common malignancies worldwide. Although the treatment outcomes of HNSCC have improved in recent years, the prognosis of patients with advanced-stage disease remains poor. Current treatment strategies for HNSCC include surgery as a primary therapy, while radio-, chemo-, and biotherapeutics can be applied as second-line therapy. Although tumor necrosis factor- $\alpha$ (TNF- $\alpha$ ) is a potent tumor suppressor cytokine, the stimulation of opposing signals impairs its clinical utility as an anticancer agent. The aim of this study was to elucidate the mechanisms regulating TNF- $\alpha$-induced opposing signals and their biological consequences in HNSCC cell lines. We determined the molecular mechanisms of TNF- $\alpha$-induced opposing signals in HNSCC cells. Our in vitro analysis indicated that one of these signals triggers apoptosis, while the other induces both apoptosis and cell survival. The TNF- $\alpha$-induced survival of HNSCC cells is mediated by the TNF receptor-associated factor 2 (TRAF2)/nuclear factor (NF)-kB-dependent pathway, while TNF- $\alpha$-induced apoptosis is mediated by mitochondrial and
\end{abstract}

Correspondence to: Dr Mohamed Hassan, Department of Surgery, Tulane University School of Medicine, 1430 Tulane Avenue, New Orleans, LA 70112, USA

E-mail: dr.hassan@gmx.de

Key words: head and neck squamous cell carcinoma, tumor necrosis factor- $\alpha$, apoptosis, c-jun $\mathrm{N}$-terminal kinase, nuclear factor- $\kappa \mathrm{B}$, apoptosis signaling regulating kinase 1 non-mitochondrial-dependent mechanisms through FADDcaspase-8-caspase-3 and ASK-JNK-p53-Noxa pathways. The localization of Noxa protein to both the mitochondria and endoplasmic reticulum (ER) was found to cause mitochondrial dysregulation and ER stress, respectively. Using inhibitory experiments, we demonstrated that the FADD-caspase-8-caspase-3 pathway, together with mitochondrial dysregulation and ER stress-dependent pathways, are essential for the modulation of apoptosis, and the NF- $\mathrm{KB}$ pathway is essential for the modulation of anti-apoptotic effects/cell survival during the exposure of HNSCC cells to TNF- $\alpha$. Our data provide insight into the mechanisms of TNF- $\alpha$-induced opposing signals in HNSCC cells and may further help in the development of novel therapeutic approaches with which to minimize the systemic toxicity of TNF- $\alpha$.

\section{Introduction}

Head and neck squamous cell carcinoma (HNSCC) is one of the leading types of cancer by incidence worldwide (1). Although the prevalence of this type of cancer is in a steady decline and treatment outcomes have improved $(2,3)$, the prognosis of patients with advanced stages of HNSCC remains poor. Tumor resistance and drug toxicity impair the clinical validity of available therapeutics, particularly in advanced stages of the disease $(4,5)$.

Tumor necrosis factor- $\alpha$ (TNF- $\alpha$ ) is a potent tumor suppressor cytokine that is a potential viable agent for tumor biotherapy (6). TNF- $\alpha$ mediates both pro- and anti-tumoral effects in the form of distinct or overlapping functions via two major receptors, $55 \mathrm{kDa}$ TNFR1 and $75 \mathrm{kDa}$ TNFR2 (7). While TNFR1 is ubiquitously expressed in normal and tumor tissues, the expression of TNFR2 is restricted to immune 
cells (8). In addition to its apoptotic proficiency, TNF- $\alpha$ is able to trigger the activity of the nuclear transcription factor, nuclear factor- $\kappa \mathrm{B}(\mathrm{NF}-\kappa \mathrm{B})$, which in turn mediates the regulation of apoptotic inhibitor genes, such as Bcl-2, Bcl-xL, cellular inhibitors of apoptosis (cIAPs), X-linked inhibitor of apoptosis (xIAP) and cFLIP $(9,10)$. While TNF- $\alpha$ shows promise as a cancer therapeutic agent, and clinical trials have shown that treatment with recombinant TNF exerts antitumor effects, there is an alarming induction of endotoxic shock and systemic toxicity following TNF- $\alpha$ administration $(11,12)$.

Apoptosis is the orderly process of programmed cell death that occurs in multicellular organisms. This tightly orchestrated process represents a vital component of cellular functioning, and is necessary for normal cell turnover and embryonic development. While apoptosis is a natural process that can block cancer development, its deregulation is implicated in the progression of tumorigenesis (13). The apoptotic process is driven by three common pathways: i) The death receptor-mediated extrinsic pathway; ii) the mitochondria-mediated intrinsic pathway; and iii) the endoplasmic reticulum (ER) stressmediated apoptotic pathway $(14,15)$. The extrinsic pathway is one of the two major apoptotic pathways whose activation is initiated by transmembrane receptor(s) through ligation to the corresponding ligand(s) or agonist(s). These receptors include FasL/FasR, TNF- $\alpha$ /TNFR1, Apo3L/DR3, Apo2L/DR4 and Apo2L/DR5, with the most well-characterized receptors being the members of the TNF receptor gene superfamily (16). The key components of these apoptotic pathways are potential targets for genetic and/or epigenetic alteration, which can lead to failure in the cellular death machinery that is thought to be the main cause of tumor progression and resistance $(17,18)$. Thus, the activation of apoptosis-associated pathways is a feasible strategy for tumor prevention and treatment.

In the present study, we provide insight into the mechanisms of TNF- $\alpha$-induced opposing signals in HNSCC cells, and describe in detail the mechanism through which TNF- $\alpha$ induces apoptosis, with the aim to develop therapeutic strategies that can minimize the systemic toxicity of this cytokine.

\section{Materials and methods}

Cells, cell culture and treatment. The HNSCC cell lines used in this study were the following: i) The human oral squamous cell carcinoma cell line, CLS-3540, obtained from CLS Cell Lines Service GmbH (Eppelheim, Germany); and ii) the human nasal septum squamous cell carcinoma cell line, RPMI2650, obtained from the American Tissue Culture Collection (ATCC, Manassas, VA, USA). The CLS-354 cells were cultivated and maintained in DMEM supplemented with $10 \%$ fetal bovine serum and 2 mM L-glutamine, while RPMI2650 cells were cultivated and maintained in EMEM media supplemented with $10 \%$ fetal bovine serum and $2 \mathrm{mM}$ L-glutamine. The treatment of the cells with TNF- $\alpha$ (\#C-63722; PromoCell $\mathrm{GmbH}$, Heidelberg, Germany) was performed at a concentration of $10 \mathrm{ng} / \mathrm{ml}$ for $48 \mathrm{~h}$. In addition, $1 \mu \mathrm{M}$ inhibitor of ASK1 (thioredoxin), $5 \mu \mathrm{M}$ inhibitor of NF- $\mathrm{NB}$ (Bay-11-7082), $10 \mu \mathrm{M}$ inhibitor of JNK (SP600125) (all from Biomol GmbH, Loerrach, Germany), $25 \mu \mathrm{M}$ of inhibitor of IRE1 $\alpha$ (irestatine; Axon Medchem, Reston, VA, USA) and $20 \mu \mathrm{M}$ inhibitor of caspase-8 (Z-IETD-FMK; R\&D Systems, Minneapolis,
MN, USA) were added to the cell culture $1 \mathrm{~h}$ prior to exposure to TNF- $\alpha$ for the indicated time period of $48 \mathrm{~h}$.

Assessment of cell survival. The cells were exposed to the recommended concentration of TNF- $\alpha(10 \mathrm{ng} / \mathrm{ml})$ before the measurement of cell viability using MTT assays (Roche, Bâle, Switzerland), as previously described (19-21). Briefly, the HNSCC cell lines were allowed to grow for $24 \mathrm{~h}$ prior to exposure to TNF- $\alpha(10 \mathrm{ng} / \mathrm{ml})$ for the indicated periods of time. The treated and control cells were then incubated with $50 \mu \mathrm{l}$ of MTT substrate $(5 \mathrm{mg} / \mathrm{ml})$ per well for $3 \mathrm{~h}$ under normal cell culture conditions. Following the removal of the culture media, the cells were lysed in $300 \mu \mathrm{l}$ of MTT lysis buffer and the relative cell number was assessed by an ELISA reader (VersaMax ELISA Microplate Reader; Molecular Devices, San Jose, CA, USA) at 570-590 nm.

RNA interference. siRNA specific to protein kinase RNA-like endoplasmic reticulum kinase (PERK; SC-36213), siRNA to human Noxa (SC-37306), as well as the scramble siRNA (included with each respective siRNA) were obtained from Santa Cruz Biotechnology (Santa Cruz, CA, USA). Knockdown experiments were carried out as recommended by the manufacturer's instructions. The cells were transfected with Lipofectamine 2000 as previously described $(19,22)$.

Western blot analysis. Western blot analysis was performed according to the standard procedures. The treated and control cells were washed twice with cold PBS and lysed with lysis buffer containing $25 \mathrm{mM}$ HEPES ( $\mathrm{pH} 7.5$ ), $0.3 \mathrm{M} \mathrm{NaCl}, 1.5 \mathrm{mM} \mathrm{MgCl}$, $0.2 \mathrm{mM}$ EDTA, $0.5 \mathrm{mM}$ DTT, $20 \mathrm{mM} \beta$-glycerolphosphate, $0.1 \mathrm{mM}$ sodium orthovanadate, $0.1 \%$ Triton X-100 and a protease inhibitor cocktail (Roche Diagnostics, Mannheim, Germany). The protein concentration was determined using Bradford Protein Assay (Bio-Rad, Hercules, CA, USA). The separation of proteins (20 g per lane) was carried out by $12 \%$ of SDS-polyacrylamide gel electrophoresis (Bio-Rad). The transfer of proteins to nitrocellulose membranes (Schleicher \& Schuell, Dassel, Germany) from SDS-PAGE was accomplished in a Hoefer TE 62X Transphor II unit. The membranes were blocked with Trisbuffered saline (TBS) buffer with 5\% non-fat dry milk (Bio-Rad) overnight at $4^{\circ} \mathrm{C}$. The blots were incubated with the following antibodies at the indicated dilutions: Anti-apoptosis signaling regulating kinase 1 (ASK1; SC-7931), 1:500; antip-ASK1 (SC-109911), 1:1,000; anti-c-jun N-terminal kinase (JNK; SC-474), 1:1,000; anti-p-JNK (SC-6254), 1:1,000; anti-p38 (SC-535), 1:1,000; anti-p-p38 (SC-7973), 1:1,000; anti-Noxa (SC-2697), 1:1,000; anti-actin (SC-1615), 1:5,000; anti-Tom20 (SC-11415), 1:100; anti-Bap31 (SC-18579), 1:500; anti-IRE1 $\alpha$ (SC-20790), 1:500; anti-PERK (SC-9477), 1:1,000; anti-activating transcription factor 4 (ATF-4; SC-200), 1:1,000;

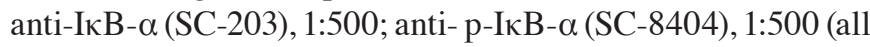
from Santa Cruz Biotechnology); anti-p-IRE1 $\alpha$ (PA1-16927; Thermo Fisher Scientific, West Palm Beach, FL, USA), 1:1,000; anti-CHOP (\#2895), 1:1,000; anti-caspase 3 (\#7190), 1:1,000; anti-caspase-9 (\#9501), 1:1,000; 1:500; anti-Fas associated via death domain (FADD; \#2782), 1:1,000; anti-phospho-FADD (\#2785), 1:500 anti-poly(ADP-ribose) polymerase (PARP; \#9542), 1:500; caspase-8 (\#9496), 1:1,000; anti-phospho- 
TRAF2 (\#13908), 1:1,000 (all from Cell Signaling Technology Inc., Danvers, MA, USA); anti-TRAF2 antibody (ab37118), 1:1,000; Abcam anti-p-IRE1 (ab48187), 1:1,000; anti-p-ATF-4 (ab28830), 1:1,000 (from Abcam, Cambridge, MA, USA), anti-eIF2 $\alpha$ antibody (LS-C285898EIF2), 1:1,000 and antiphospho-eIF2 $\alpha$ antibody (LS-C191237), 1:1,000 (from LSBio, Seattle, WA, USA).

Immunofluorescence staining. The RPMI2650 cells were allowed to grow for $24 \mathrm{~h}$ prior to exposure to TNF- $\alpha$ for the indicated periods of time. The cells were then subjected to immunofluorescence staining as described previously (19). Primary antibodies, including anti-Noxa (SC-2697), 1:200; anti-Tom20 (SC-11415), 1:200; anti-Bap31 (SC-18579), 1:200 (all from Santa Cruz Biotechnology) were allowed to bind for $2 \mathrm{~h}$ at room temperature. Subsequently, the cells were washed 3 times in PBS and incubated with Alexa Fluor-labeled secondary antibodies, including, Alexa Fluor 488 Dye and Alexa Fluor 555 Dye and Alexa Fluor 647 Dye (all from Thermo Fisher Scientific) for $2 \mathrm{~h}$ at room temperature. Following an additional 3 washes in PBS, the cells were mounted using DAKO mounting medium. Photomicrographs were acquired on a Leica fluorescence microscope (Leica, Wetzlar, Germany).

Electrophoretic mobility shift assay (EMSA). The details of EMSA have been described elsewhere $(19,23)$. Briefly, the nuclear extracts of the treated and control cells were prepared by the addition of cell lysis buffer [20 mM HEPES ( $\mathrm{pH} 7.9$ ), $10 \mathrm{mM} \mathrm{NaCl}, 0.2$ EDTA, 2 mM DTT, 1 mM Na Vanadate, and $1 \mathrm{mM}$ proteinase inhibitor], and the nuclei were precipitated by centrifugation at $10,000 \times \mathrm{g}$ for $3 \mathrm{~min}$ and the subsequent addition of nuclear lysis buffer [20 mM HEPES ( $\mathrm{pH} 7.9$ ), $1.5 \mathrm{mM} \mathrm{MgCl}_{2}, 1 \mathrm{mM} \mathrm{Na}$ Vanadate, $420 \mathrm{mM} \mathrm{NaCl}, 0.2$ EDTA, $2 \mathrm{mM}$ DTT, $25 \%$ glycerol and $1 \mathrm{mM}$ protease inhibitor]. The double-stranded synthetic oligonucleotides carrying a defined binding site for AP-1, p53 and NF- $\kappa$ B (Santa Cruz Biotechnology), ATF-3 (5'-GTGACGT[AC] [AG]-3') were then end-labeled with $\left[\mathrm{y}^{32} \mathrm{P}\right]$ ATP (Hartmann Analytika, Munich, Germany) in the presence of T4 polynucleotide kinase (GeneCraft, Münster, Germany). Briefly, a reaction volume of $20 \mu \mathrm{l}$ containing $10 \mathrm{pmol}(2 \mu \mathrm{l})$ of oligonucleotides carrying a defined binding site of the above mentioned transcription factors, $5 \mu \mathrm{Ci}$ of $\left[\mathrm{y}^{32} \mathrm{P}\right]$ ATP $(5 \mu \mathrm{l}), 4 \mu \mathrm{l}$ T4 kinase buffer $(5 \mathrm{X})$ and $1 \mu \mathrm{l}$ T4 kinase and $3 \mu \mathrm{l} \mathrm{H}_{2} \mathrm{O}$. Following incubation at $37^{\circ} \mathrm{C}$ for $30 \mathrm{~min}$, the labeled oligonucleotides were purified using the oligonucleotide purification kit (Qiagen, Hilden, Germany) and stored at $-20^{\circ} \mathrm{C}$ until use. Approximately $4 \mu \mathrm{g}$ of nuclear extracts were bound to a labeled probe in a total volume of $30 \mu \mathrm{l}$ for $30 \mathrm{~min}$ at room temperature in binding buffer (10 mM Tris, pH 7.5; 50 mM NaCl, 1 mM EDTA; $1 \mathrm{mM} \mathrm{MgCl}_{2} ; 0.5 \mathrm{mM}$ DTT and $4 \%$ glycerol). The specificity of the binding was analyzed by competition with an unlabeled oligonucleotide assay. The competition assay was performed in the same manner, except that unlabeled probes containing oligonucleotide sequences (binding sites) were incubated with nuclear extracts for $20 \mathrm{~min}$ at room temperature before adding the labeled probes. Electrophoresis was performed for $3 \mathrm{~h}$ at $100 \mathrm{~V}$ in $0.5 \mathrm{X}$ Tris-borate-EDTA running buffer at room temperature. The dried gel was visualized by exposure to high performance autoradiography film.
Detection of apoptosis using Annexin V/propidium iodide. The analysis of the TNF- $\alpha$-induced apoptosis of the CLS-354 and RPMI2650 cells was performed by flow cytometry using Annexin V-FITC/propidium iodide (PI); (Vybrant; Invitrogen, Karlsruhe, Germany). Following the incubation of treated and control cells with Annexin/PI for $15 \mathrm{~min}$ at room temperature with protection from light, the cells were measured as previously described $(19,21)$. Cells stained with Annexin were identified as early apoptotic cells, while cells stained with both Annexin and PI were identified as late apoptotic cells.

Measurement of mitochondrial membrane potential $(\Delta \psi m)$ using JC-1. The CLS-354 and RPMI2650 cells were stained with $10 \mu \mathrm{M} \mathrm{JC}-1$ for $30 \mathrm{~min}$ at room temperature in the dark. The intensities of red $(>550 \mathrm{~nm})$ and green $(520-530 \mathrm{~nm})$ fluorescence of 50,000 individual cells were analyzed by flow cytometry as previously described $(19,24)$. At a low $\Delta \psi \mathrm{m}$, JC-1 is predominantly a monomer that yields green fluorescence with the emission of $530 \pm 15 \mathrm{~nm}$, while at a high $\Delta \psi \mathrm{m}$, the dye aggregates yielding a red to orange colored emission $(590 \pm 17.5 \mathrm{~nm})$. Therefore, a decrease in the aggregate fluorescent count is indicative of depolarization, whereas an increase is indicative of hyperpolarization.

Statistical analysis. Data were expressed as the means \pm SD. Statistical comparisons were performed with one-way ANOVA followed by Dunnett's test. Statistical differences between 2 groups were determined using the unpaired Student's t-test. $\mathrm{P}<0.05$ was considered to indicate a statistically significant difference. All statistical analyses were performed using SPSS statistical software (version 16.0; SPSS, Chicago, IL, USA).

\section{Results}

TNF- $\alpha$-induced apoptosis of HNSCC cells is mediated by mitochondrial-dependent mechanisms. Initially, we determined the $\mathrm{IC}_{50}$ value of TNF- $\alpha$ in the HNSCC cells. The CLS-354 and RPMI2650 cell lines were allowed to grow for $24 \mathrm{~h}$ prior to exposure to various concentrations of TNF- $\alpha$ $(1.0,2.0,3.0,4.0,5.0,10,15$ and $20 \mathrm{ng} / \mathrm{ml})$ for a time period of $24 \mathrm{~h}$ or $48 \mathrm{~h}$, and the viability of both treated and control cells was then measured by cell viability assay following incubation with MTT substrate. MTT assay revealed an $\mathrm{IC}_{50}$ value of TNF- $\alpha(10 \mathrm{ng} / \mathrm{ml})$ which was able to induce a $50 \%$ decrease in the cell number after $48 \mathrm{~h}$ in both the CLS-354 and RPMI2650 cells, when compared to the untreated controls (data not shown). We then performed a time course experiment to confirm the effect of the determined $\mathrm{IC}_{50}$ value of TNF- $\alpha$ on the viability of HNSCC cells by MTT assay. The CLS-354 and RPMI2650 cell lines were cultured for $24 \mathrm{~h}$ prior to exposure to TNF- $\alpha(10 \mathrm{ng} / \mathrm{ml})$ for regulated time intervals up to $72 \mathrm{~h}$. The data obtained from MTT assay (Fig. 1A) revealed a time-dependent reduction in cell viability in both the CLS-354 and RPMI2650 cells in response to treatment with TNF- $\alpha$. TNF- $\alpha$-induced cell growth inhibition was noted first at $12 \mathrm{~h}$ post-treatment and increased thereafter to reach a maximum by $72 \mathrm{~h}$. After the optimal concentration of TNF- $\alpha(10 \mathrm{ng} / \mathrm{ml})$ and time $(48 \mathrm{~h})$ had been determined, we set out to perform all functional experiments under the same conditions. 

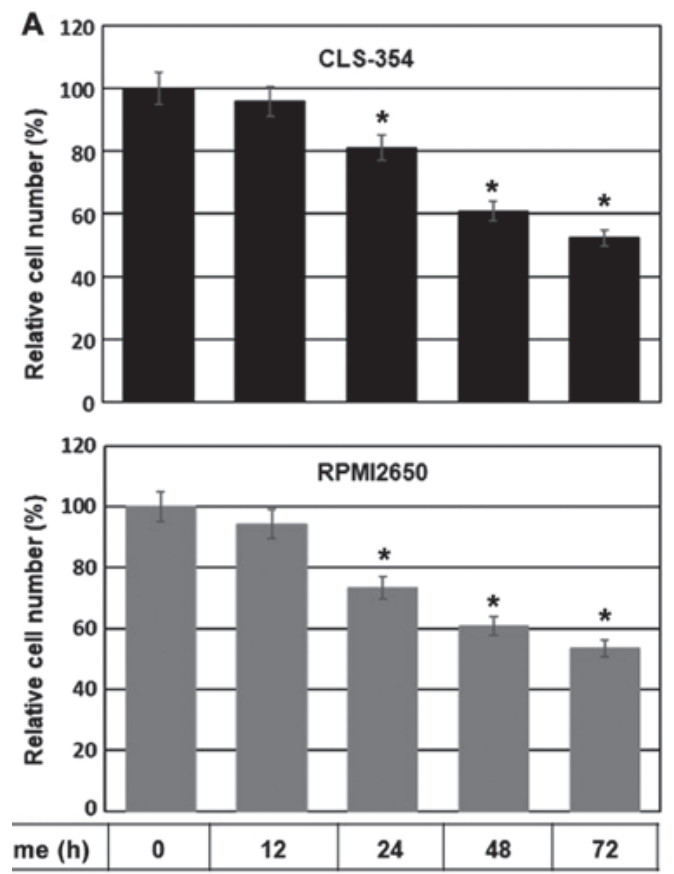

C

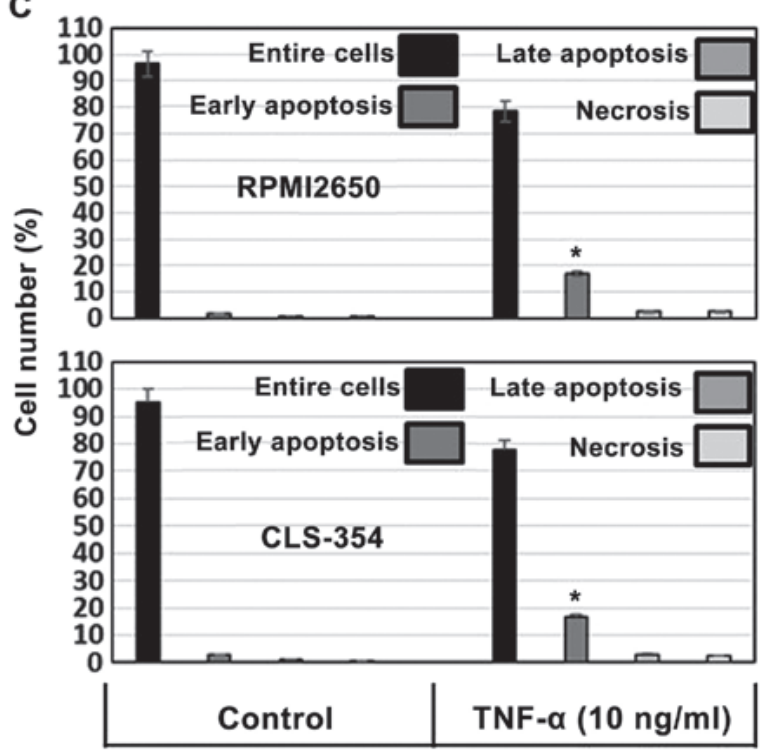

B

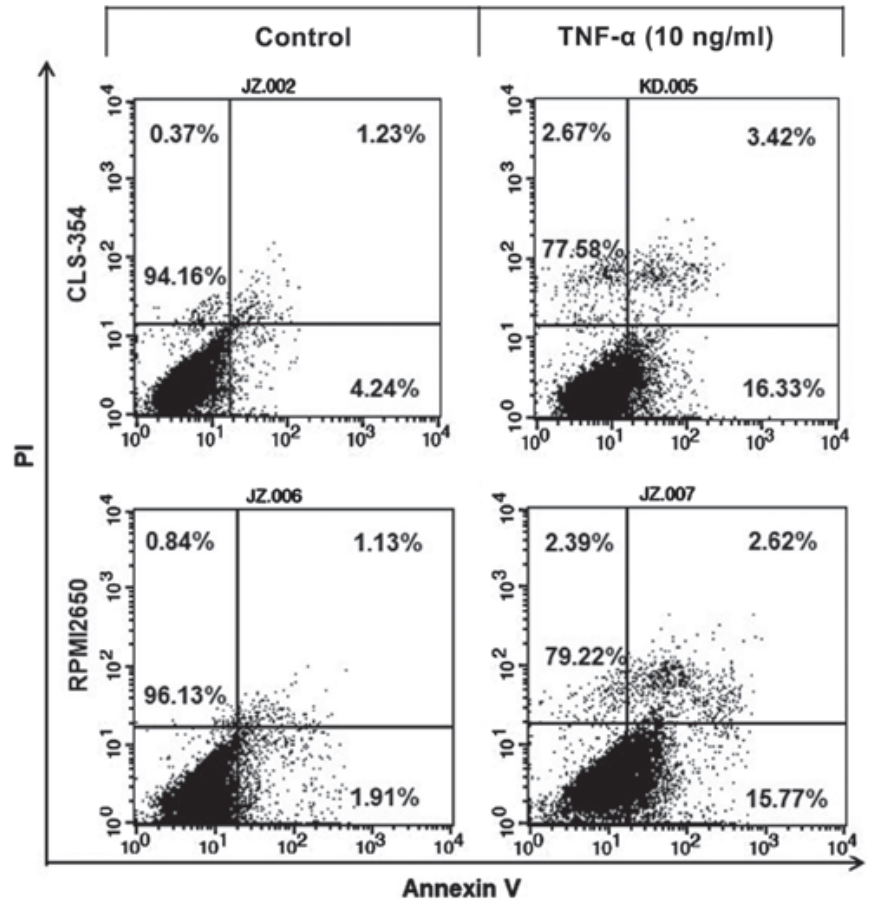

D

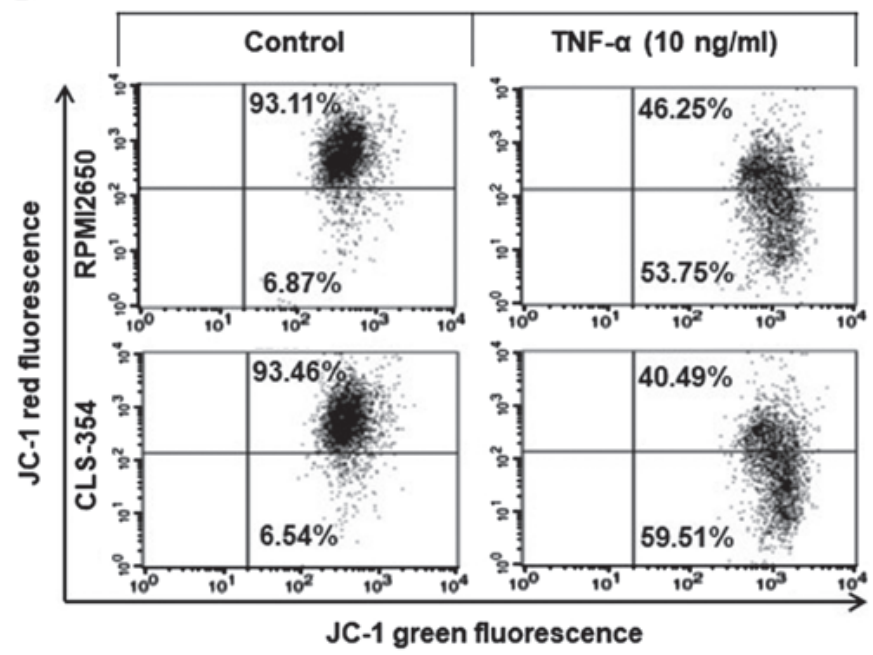

Figure 1. (A) Time course-dependent inhibition of the growth rate of head and neck squamous cell carcinoma (HNSCC) cells in response to exposure to TNF- $\alpha$. Relative cell number (\%) assessed by MTT assay following the exposure of the HNSCC cell lines, CLS-345 and RPMI2650, to TNF- $\alpha$ (10 ng/ml) for regulated time intervals up to $72 \mathrm{~h}$. Data are presented as the means $\pm \mathrm{SD}(\mathrm{n}=4)$. ${ }^{*} \mathrm{P}<0.05$, significantly different from the control as shown by ANOVA and Dunnett's test. (B) Flow cytometric analysis using Annexin V/propidium iodide (PI) staining demonstrating the TNF- $\alpha$-induced apoptosis of the HNSCC cell lines, CLS-345 and RPMI2650. (C) Data of of Annexin V/PI are presented as the means $\pm \mathrm{SD}(\mathrm{n}=3)$. " $\mathrm{P}<0.05$, significantly different from the control as shown by ANOVA and Dunnett's test. (D) Flow cytometric analysis using JC-1 staining demonstrating the loss of mitochondrial membrane potential ( $\Delta \psi \mathrm{m})$ in TNF- $\alpha$-treated cells.

Subsequently, we investigated whether the TNF- $\alpha$-induced death of HNSCC cells is mediated by an apoptotic mechanism. Accordingly, we analyzed the TNF- $\alpha$-induced cell death of both the CLS-354 and RPMI2650 cells using an apoptosisspecific assay. According to apoptosis-specific protocol, early apoptotic cells are Annexin V-positive and PI-negative, while late apoptotic cells are Annexin V-positive and PI-positive. In accordance with the protocol, our results revealed a significant increase in the percentage of early cell death in both the CLS-354 (16.33\%) and RPMI5026 (15.77\%) cells, while the level of late apoptotic cells was $\sim 3.42 \%$ in the CLS-354 cells and $2.62 \%$ in the RPMI5026 cells following treatment with TNF- $\alpha$ for 48 h (Fig. 1B). However, statistical analysis of the 3 independent experiments demonstrated a significant elevation of early apoptosis in both cell lines ( $\mathrm{P}<0.05$; Fig. 1C), an evidence of the involvement of an apoptotic mechanism in the regulation of the TNF- $\alpha$-induced death of HNSCC cells.

To determine whether TNF- $\alpha$-induced apoptosis is associated with mitochondrial dysregulation, the RPMI2650 and CLS-354 cells were treated with TNF- $\alpha$ for $48 \mathrm{~h}$, and the treated and control cells were then subjected to flow cytometric analysis using JC-1 staining. As expected, the results of 

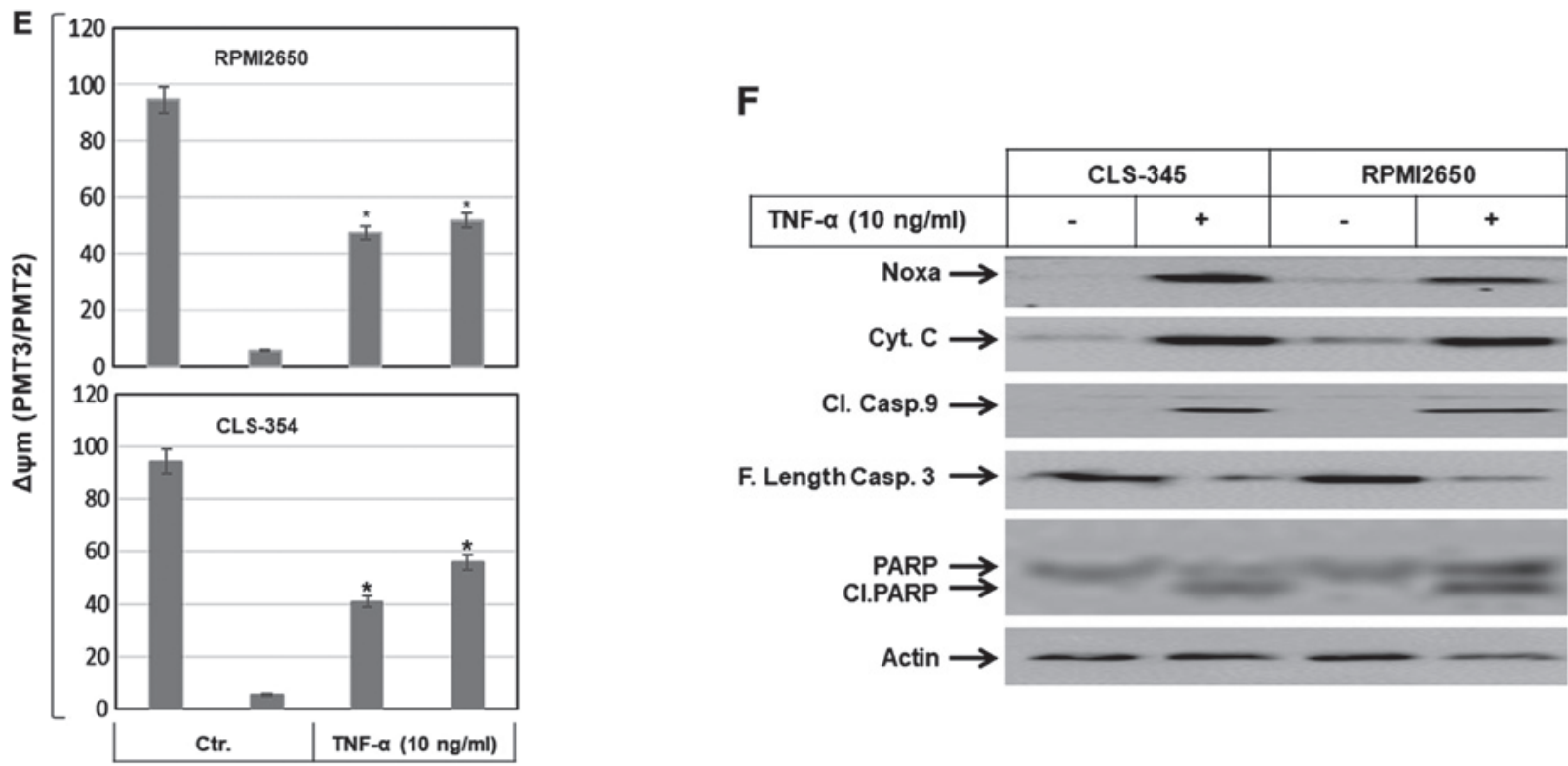

G

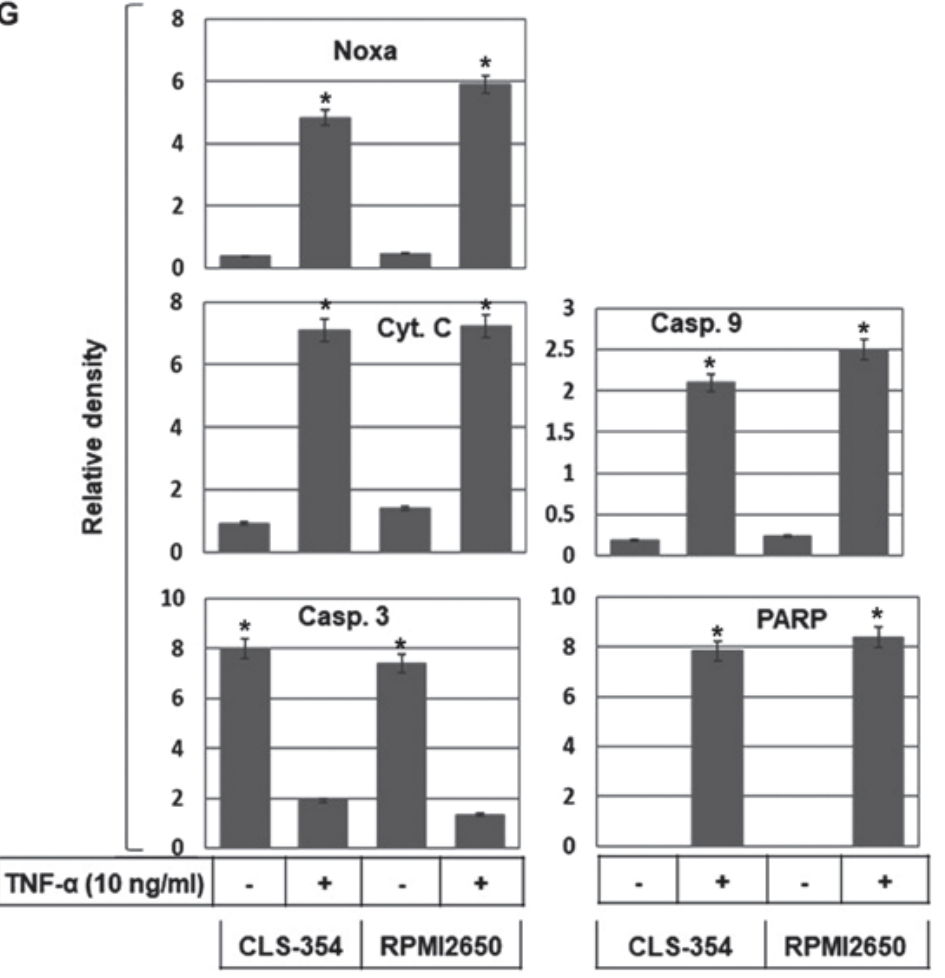

Figure 1. Continued. (E) Data of JC-1 staining are presented as the means $\pm \mathrm{SD}(\mathrm{n}=3)$. In each treatment group, the first one of the two bars represents the portion of the cells that do not show loss of mitochondrial membrane potential, while the second bar represents the portion of cells that show the loss of mitochondrial membrane potential. ${ }^{*} \mathrm{P}<0.05$, significantly different from the control as shown by ANOVA and Dunnett's test. (F) Western blot analysis demonstrating the induction of Noxa expression, the release of cytochrome $c$ (Cyt.c), and the cleavage of caspase-9, caspase-3 and PARP in response to the treatment of the HNSCC cell lines, CLS-345 and RPMI2650, with TNF- $\alpha$ for $48 \mathrm{~h}$. Actin was used as an internal control for loading and transfer. (G) Analyses of band intensity on films are presented as the relative ratio of Noxa to actin, released Cyt.c to actin, cleaved caspase-9 (Cl.Casp.9) to actin, cleaved caspase-3 (Cl.casp.3) to actin and cleaved PARP (Cl.PARP) to actin. Bars represent the means $\pm \mathrm{SD}(\mathrm{n}=3)$. ${ }^{*} \mathrm{P}<0.05$ vs. control.

flow cytometric analysis (Fig. 1D and E) demonstrated the loss of $\Delta \psi \mathrm{m}$ in both cell lines when compared to the control cells, suggesting that the TNF- $\alpha$-induced apoptosis of HNSCCs is mediated by a mitochondrial dysregulation-dependent mechanism. Based on its role in the modulation of mitochondrial dysregulation (21), we set out to analyze the expression of the pro-apoptotic protein, Noxa, in the treated and control cells. The analysis of the total cell lysates of the RPMI2650 and
CLS-354 cells using western blot analysis (Fig. 1F and G) revealed the induction of Noxa protein in response to treatment with TNF- $\alpha$, suggesting an important role for Noxa protein in the TNF- $\alpha$-induced apoptosis of HNSCC cells. We then confirmed the TNF- $\alpha$-induced apoptosis of HNSCC cells at the molecular level. Accordingly, we analyzed hallmarks of apoptosis, such as cytochrome $c$, caspase-9, caspase-3, and PARP by western blot analysis. Treatment of both the 
A
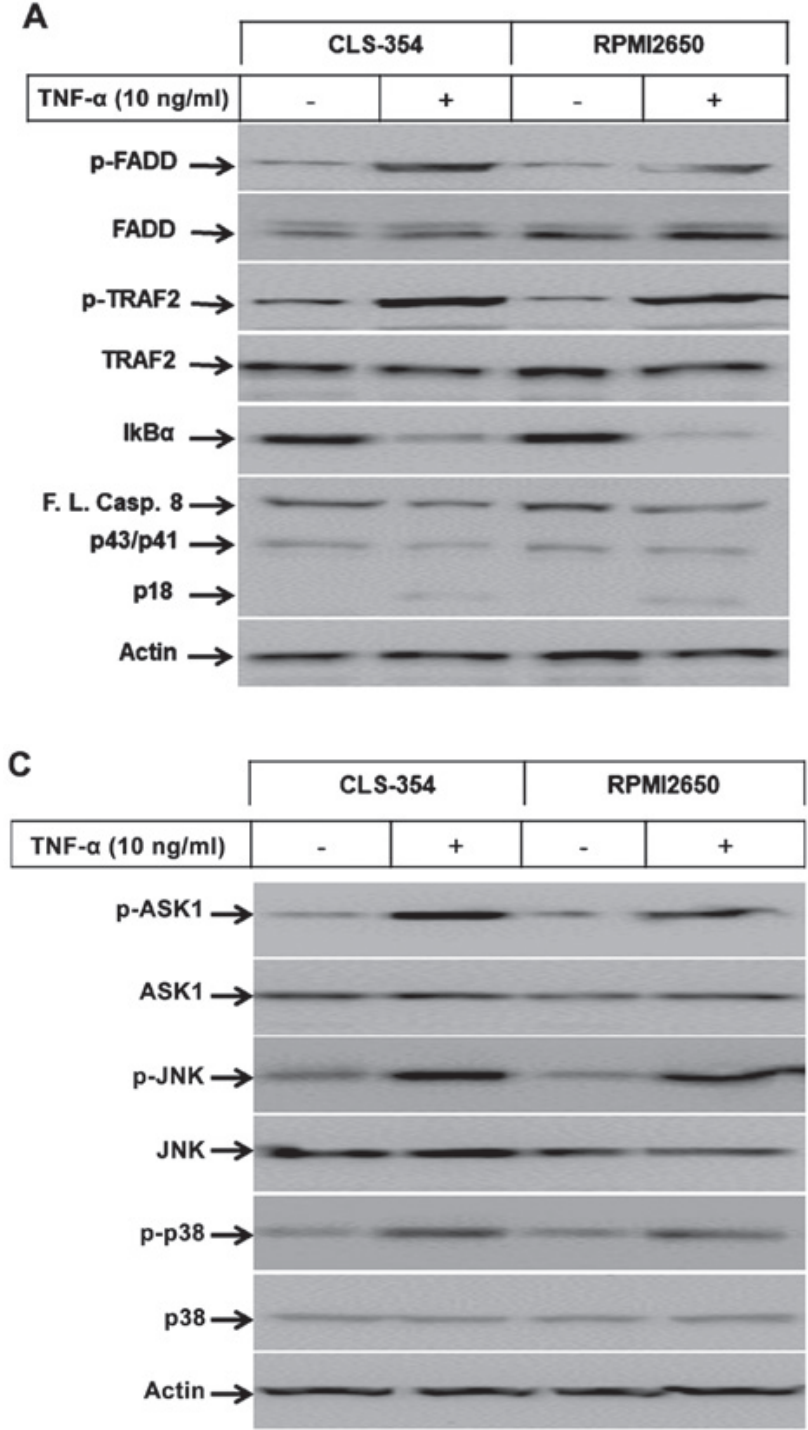

E

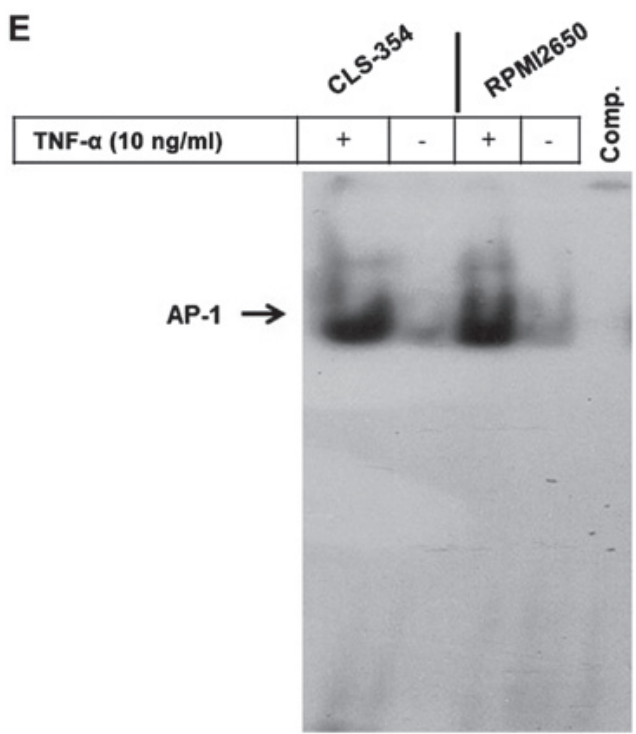

B

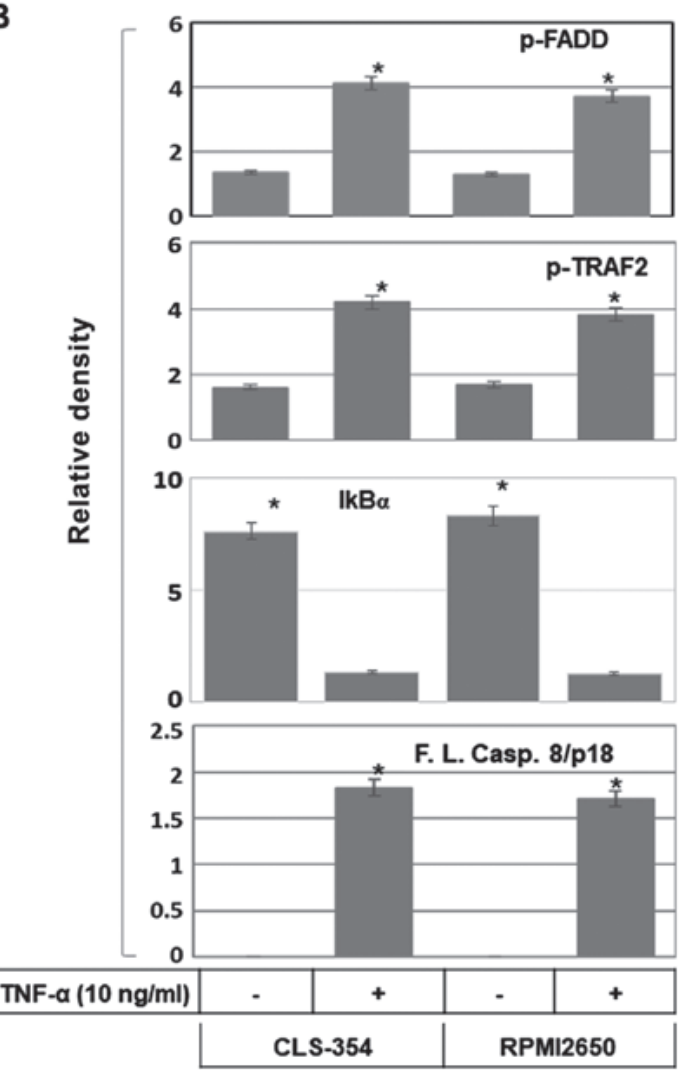

D
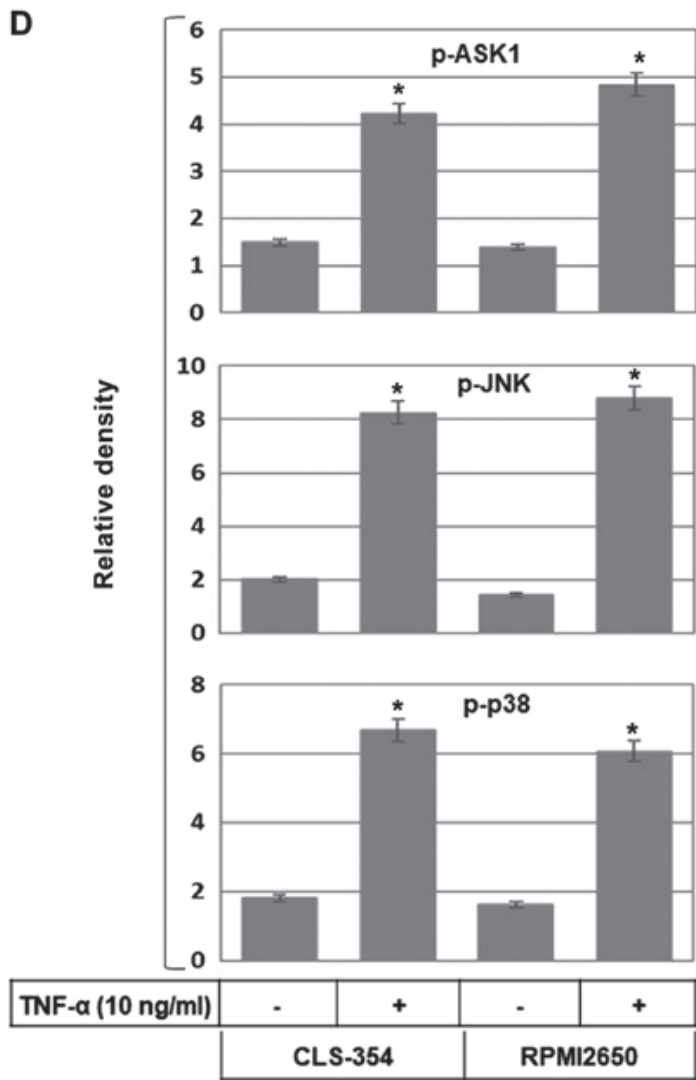

Figure 2. (A) Western blot analysis demonstrating the phosphorylation of FADD and TRAF2 proteins, and the degradation of IкB $\alpha$ and the cleavage of caspase-8 in response to the exposure of head and neck squamous cell carcinoma (HNSCC) cell lines, CLS-345 and RPMI2650, to TNF- $\alpha$. Actin was used as an internal control for loading and transfer. (B) Analyses of band intensity on films are presented as the relative ratio of p-FADD to actin, p-TRAF2 to actin, IKB $\alpha$ to actin and cleaved caspase-8/p18 (Cl.casp.8/p18) to actin. Bars represent the means $\pm \mathrm{SD}(\mathrm{n}=3)$. " $\mathrm{P}<0.05$ vs. control. (C) Western blot analysis demonstrating the phosphorylation of ASK1, JNK and p38 kinase in response to the exposure of the HNSCC cell lines, CLS-345 and RPMI2650, to TNF- $\alpha$. Actin was used as an internal control for loading and transfer. (D) Analyses of band intensity on films are presented as the relative ratio of p-ASK1 to actin, p-JNK to actin andp-p38 to actin. Bars represent the means $\pm \mathrm{SD}(\mathrm{n}=3)$. ${ }^{*} \mathrm{P}<0.05$ vs. control. EMSA demonstrates the enhancement of the DNA-binding activity of the transcription factor, (E) AP-1. 

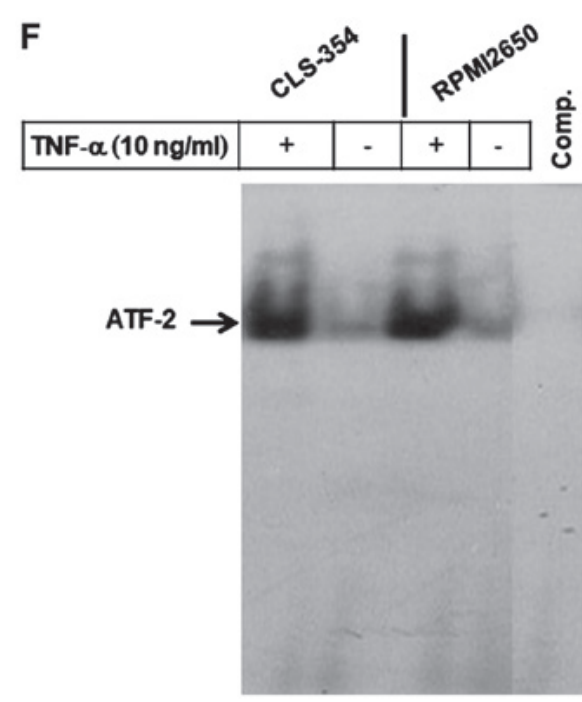
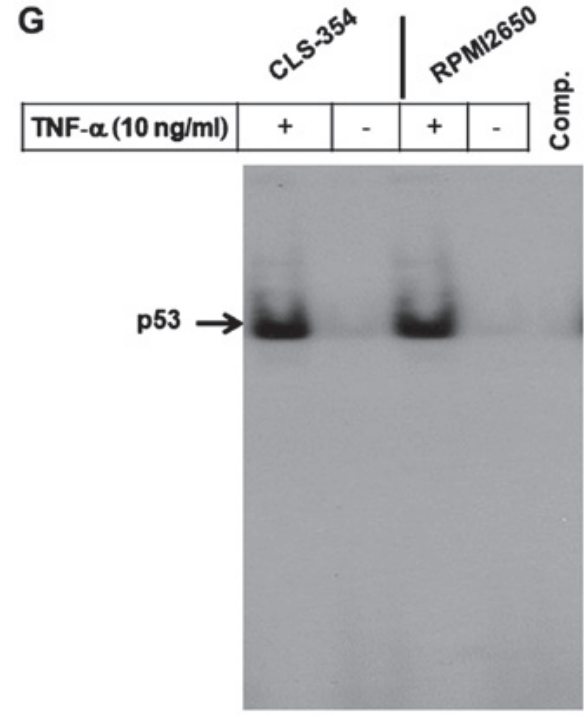
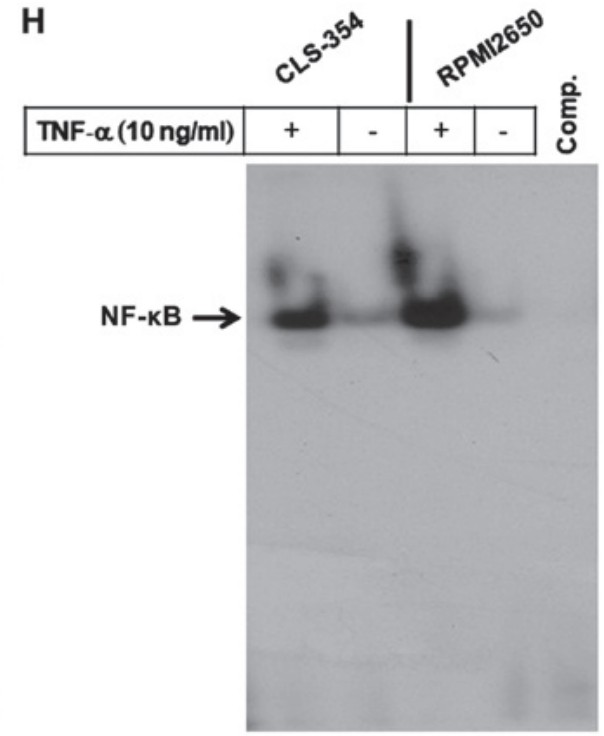

Figure 2. Continued. EMSA demonstrates the enhancement of the DNA-binding activity of the transcription factors, $(\mathrm{F}) \mathrm{ATF}-2$, $(\mathrm{G}) \mathrm{p} 53$ and $(\mathrm{H}) \mathrm{NF}-\kappa \mathrm{B}$ in response to the treatment of the HNSCC cell lines, CLS-345 and RPMI2650, with TNF- $\alpha$. Data are representative of 3 independent experiments.

RPMI2650 and CLS-354 cells with TNF- $\alpha$ was found to enhance the release of mitochondrial cytochrome $c$ into the cytoplasm, as well as the cleavage of caspas-9, caspase-3 and PARP (Fig. 1F and G).

TNF- $\alpha$ triggers the activation of pro- and anti-apoptoticdependent pathways in HNSCC cells. To further investigate the mechanisms associated with the TNF- $\alpha$-induced effects on HNSCC-derived cell lines, the RPMI2650 and CLS-354 cells were treated with TNF- $\alpha$ for $48 \mathrm{~h}$. Total cell lysate and nuclear extracts were prepared for western blot analysis and EMSA, respectively. We analyzed the possible proteins that can be targeted by the activation of the TNF receptor, such as FADD, TRAF2 and caspase-8, as well as the regulatory proteins of the NF- $\mathrm{B}$ and MAP kinase pathways. Treatment of both the RPMI2650 and CLS-354 cells with TNF- $\alpha$ enhanced the phosphorylation levels of FADD and TRAF2, the degradation of $\mathrm{I} \kappa \mathrm{B} \alpha$, and the cleavage of caspase-8, without any alterations in the expression levels of FADD or TRAF2 (Fig. 2A and B). In addition, treatment of both the RPMI2650 and CLS-354 cells with TNF- $\alpha$ induced the phosphorylation of ASK1, JNK and p38, without influencing their basal expression (Fig. 2C and D). The analysis of the nuclear extracts of the TNF- $\alpha$-treated and control cells using EMSA revealed the activation of AP-1 (Fig. 2E), ATF-2 (Fig. 2F), p53 (Fig. 2G) and $\mathrm{NF}-\kappa \mathrm{B}$ (Fig. $2 \mathrm{H})$, suggesting an important role for these transcription factors in the modulation of TNF- $\alpha$-induced effects in HNSCC derived cell lines.

Subcellular localization of TNF- $\alpha$-induced Noxa protein to both the mitochondria and ER. To investigate whether TNF- $\alpha$ induced Noxa protein is localized to the mitochondria and/or the ER, the RPMI2650 and CLS-354 cells were treated with the indicated concentration of TNF- $\alpha$ for $48 \mathrm{~h}$, and the subcellular localization of Noxa protein was then analyzed in both treated and control cells using immunofluorescence staining and western blot analysis of mitochondrial and ER fractions. Immunofluorescence staining using anti-Noxa, anti-Tom 20 (marker for mitochondria) and anti-Bap31 (marker for ER) antibodies revealed the expression of Noxa protein (green) in the treated RPMI2650 cells, whereas the expression of Tom 20 and Bap31 proteins was observed in both the treated and control cells (Fig. 3A). As expected, the merge of Noxa and Tom 20 revealed the subcellular localization of Noxa protein to the mitochondria, and the merge of Noxa and Bap31 confirmed the subcellular localization of Noxa protein to ER (Fig. 3A). We further confirmed the subcellular localization of TNF- $\alpha$ induced Noxa protein via the analysis of mitochondrial and ER fractions of the treated and control cells (Fig. 3B and C). First, we assessed the purity of both mitochondrial and ER fractions by western blot analysis using anti-Tom 20 and anti-Bap31, respectively. The detection of Noxa protein in the mitochondrial fractions of TNF- $\alpha$-treated cells confirmed the subcellular localization of Noxa protein to the mitochondria, while the detection of Noxa proteins in the ER fraction of TNF- $\alpha$-treated cells confirmed the subcellular localization of Noxa protein to the ER (Fig. 3B and C). These data suggest an important role for the subcellular localization of Noxa in the modulation of TNF- $\alpha$-induced apoptosis via a mechanism mediated by mitochondrial dysregulation and ER stress-dependent pathways.

Induction of ER stress-associated pathways by TNF- $\alpha$ in HNSCC cells. Western blot analysis and EMSA of the total cell lysates and nuclear extracts of the TNF- $\alpha$-treated and control cells were used to examine whether the subcellular localization of Noxa proteins to ER influences the ER stress-dependent pathways. Western blot analysis (Fig. 4A and B) demonstrated the ability of TNF- $\alpha$ to enhance the phosphorylation of PERK, IRE1 $\alpha$, eIf $2 \alpha$ and ATF-4 proteins together with the expression of CHOP, without influencing the expression levels of PERK, IRE1 $\alpha$ eIf $2 \alpha$ or ATF- 4 proteins. EMSA (Fig. 4C) revealed the enhancement of the DNA-binding activity of the transcription factor ATF-3 in response to treatment of the HNSCC cells with TNF- $\alpha$. Taken together, these data address an essential role for Noxa protein in the modulation of TNF- $\alpha$-induced ER stress and subsequent apoptosis. 
A

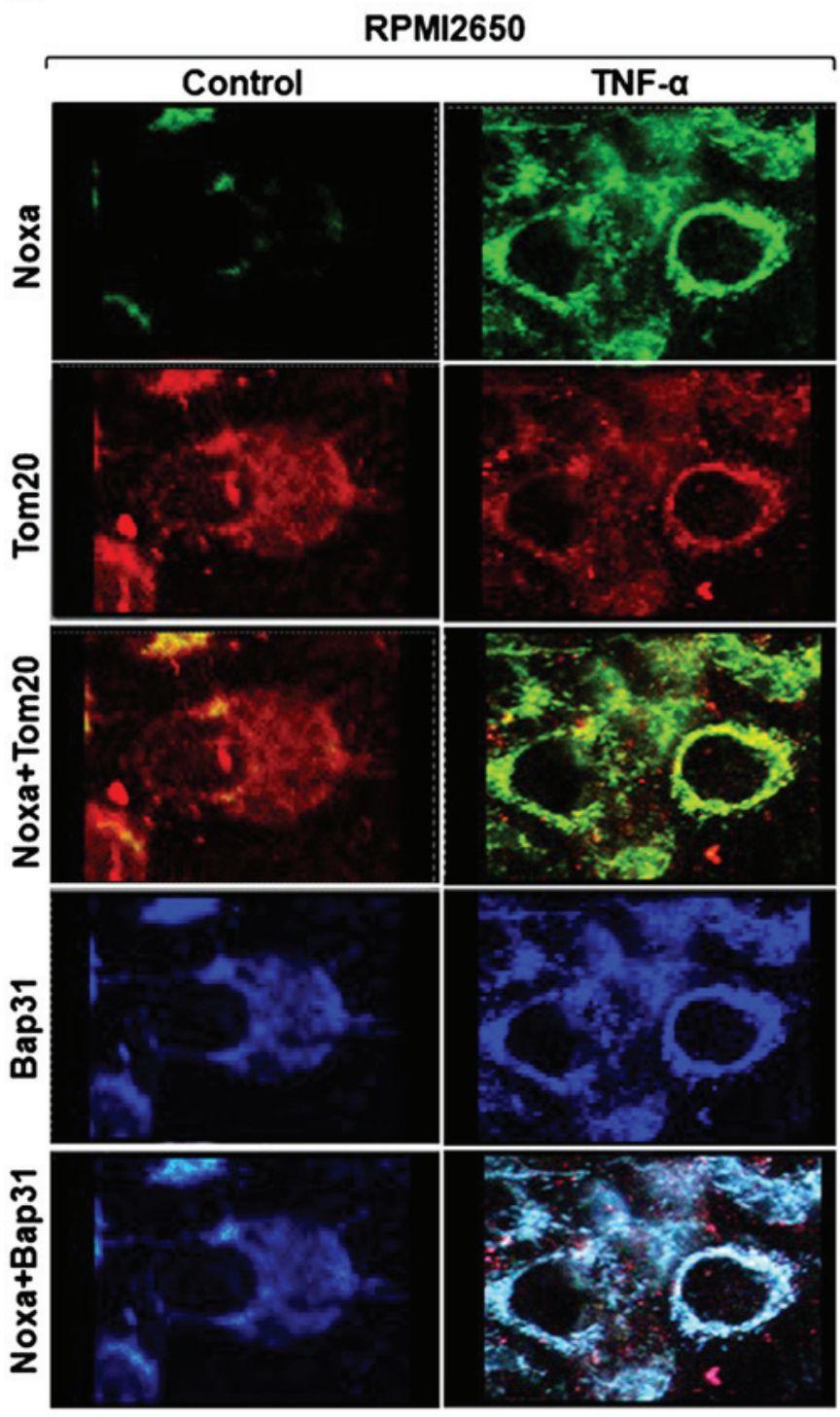

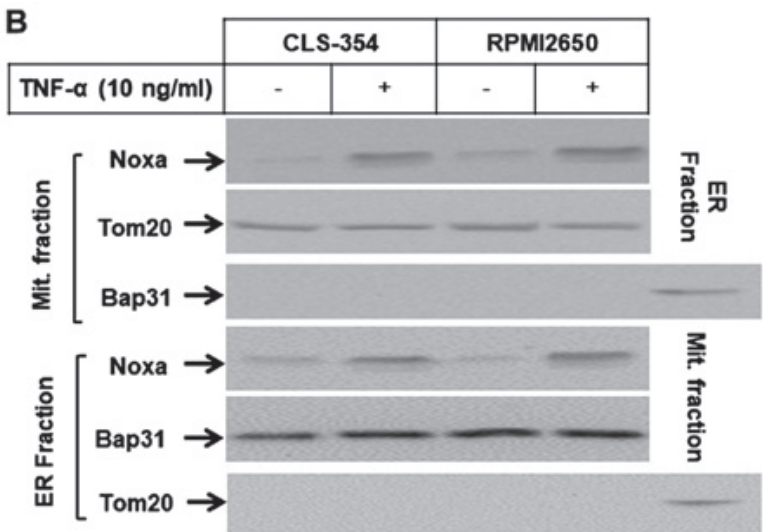

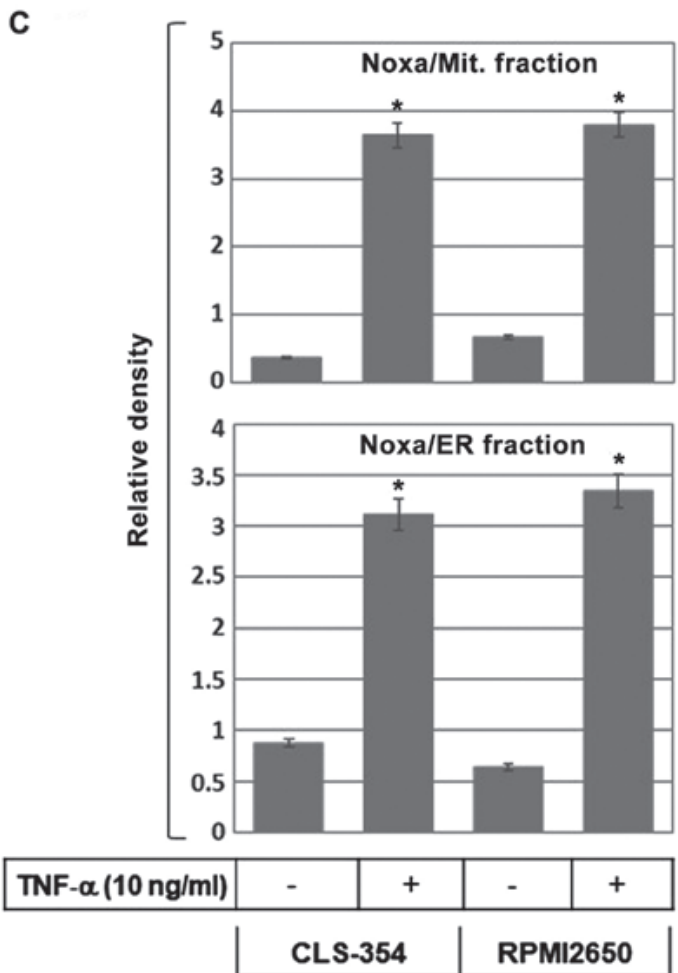

Figure 3. Subcellular localization of Noxa protein to both the mitochondria and endoplasmic reticulum (ER) in TNF- $\alpha$-treated and control RPMI2650 cells (A) Immunofluorescence (IF) staining: RPMI2650 cells were treated with TNF- $\alpha$ for $48 \mathrm{~h}$ prior to staining with anti-Noxa, Tom20 (mitochondrial marker) and Bap31 (ER marker). The subcellular localization of Noxa (green) to mitochondria (red) and the overlay of Noxa with Tom20 staining demonstrates the localization of Noxa to the mitochondria (yellow), when compared with control cells. The localization of Noxa (green) to ER (blue) and the overlay of Noxa with Bap31 staining demonstrates the localization of Noxa to ER (turquoise), when compared with control cells. (B) Western blot analysis using the mitochondrial fraction (Mit.fraction) and ER fraction from both the CLS-354 and RPMI2650 cells following treatment with TNF- $\alpha$ for $48 \mathrm{~h}$. The detection of Noxa in the mitochondrial and ER fractions of the CLS-354 and RPMI2650 cells following treatment with TNF- $\alpha$ was used to confirm the localization of Noxa protein to both the mitochondria and ER. The purity of both the mitochondrial and ER fractions was verified by the detection of the mitochondrial protein, Tom 20, in the mitochondrial fraction and the detection of Bap31 in the ER fraction. (C) Analyses of band intensity on films are presented as the relative ratio of Noxa to Tom 20 in the mitochondrial fraction and Noxa to Bap31 in the ER fraction. Bars represent the means \pm SD ( $n=3) ;{ }^{*} \mathrm{P}<0.05$ vs. control.

TNF- $\alpha$-induced apoptosis is mediated by mitochondrial-and non-mitochondrial-dependent pathways and is enhanced by the inhibition of $N F-\kappa B$. We then wished to elucidate the pathways essential for the modulation of TNF- $\alpha$-induced apoptosis. The RPMI2650 and CLS-354 cell lines were transfected with PERK-specific or Noxa-specific siRNAs, or treated with the inhibitors of caspase-8 (I.Casp.8), ASK1 (thioredoxin), JNK (SP600125), IRE1 $\alpha$ (Irestatin), or NF- $\mathrm{B}$ (Bay11-7082) prior to exposure to TNF- $\alpha$ for $48 \mathrm{~h}$. First, we examined the efficiency of the specific siRNAs against Noxa and PERK using western blot analysis of the transfected and control cells before and after exposure to TNF- $\alpha$. Western blot analysis revealed the abrogation of Noxa (Fig. 5A and B) and PERK (Fig. 5C and D) and TNF- $\alpha$-induced Noxa expression. We then examined the viability of the treated and control cells by MTT assay (Fig. 5E). There was a marked inhibition of the viability of both the RPMI2650 and CLS-354 cells in response to treatment with TNF- $\alpha$, while the knockdown of Noxa protein was found to mostly, although not completely block the TNF- $\alpha$-induced decrease in cell viability (Fig. 5E). By contrast, the knockdown of PERK by its specific siRNA, the inhibition of caspase- 8 by its specific inhibitor, the inhibition of ASK1 by thioredoxin, 

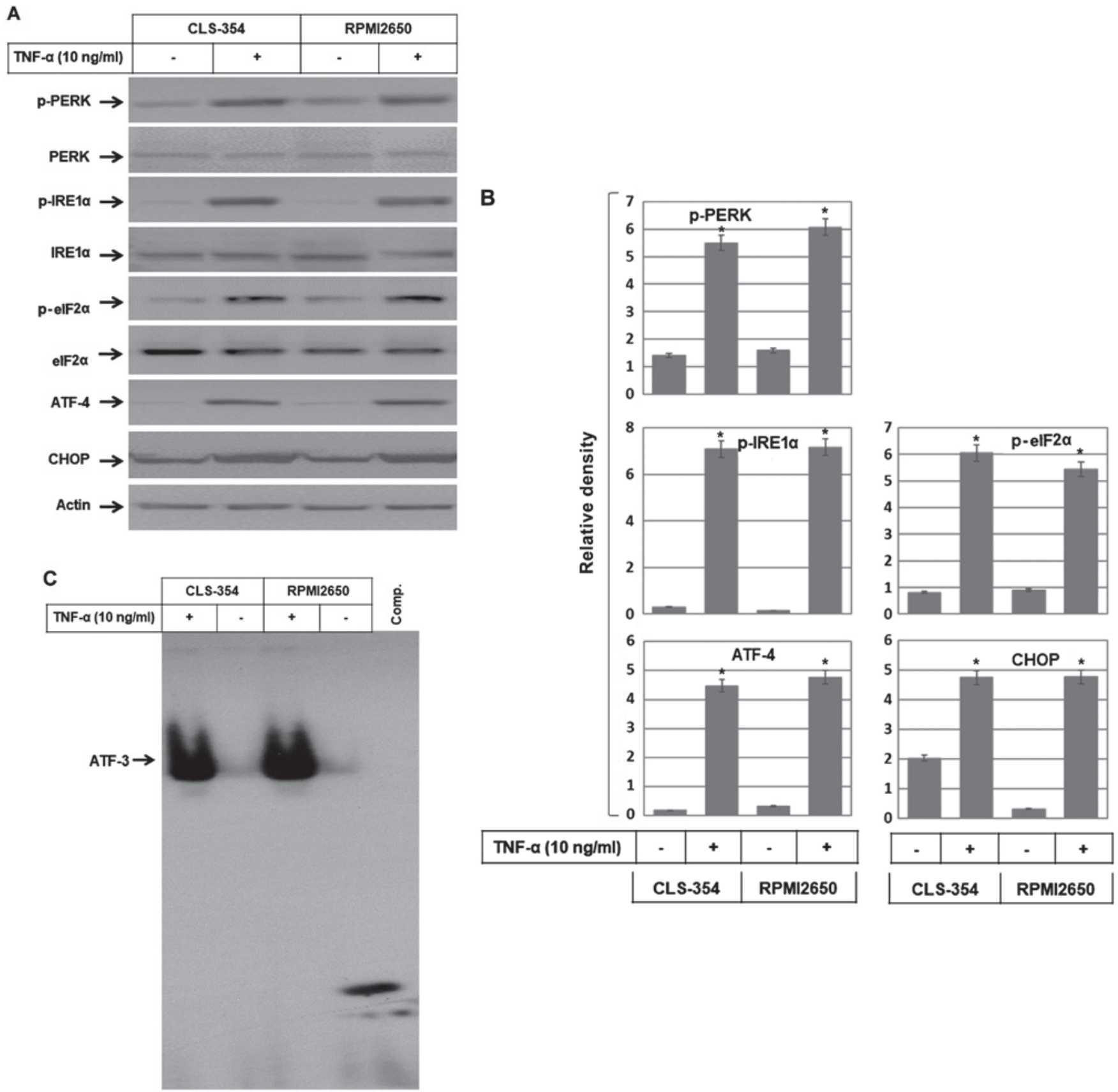

Figure 4. (A) Western blot analysis demonstrating the phosphorylation of PERK, IRE $\alpha$ and the induction of the phosphorylation of eIf2 $\alpha$, and the expression of ATF-4 and CHOP in response to treatment of the CLS-354 and RPMI2650 cells with TNF- $\alpha$. Actin was used as an internal control for loading and transfer. Data are representative of 3 independent experiments. (B) Analyses of band intensity on films are presented as the relative ratio of p-PERK to actin, p-IRE $\alpha$ to actin, p-elf $2 \alpha$ to actin, ATF-4 to actin and CHOP to actin. Bars represent the means $\pm \mathrm{SD}$ ( $n=3$ ). ${ }^{\text {P }} \mathrm{P}<0.05$ vs. control. (C) EMSA demonstrating the enhancement of the DNA-binding activity of the transcription factor ATF-3 in response to the treatment of the CLS-354 and RPMI2650 cells with TNF- $\alpha$. Data are representative of 3 independent experiments.

the inhibition of JNK by SP600125, and the inhibition of IRE1 $\alpha$ by irestatin only partially blocked the TNF- $\alpha$-induced decrease in the viability of both cell lines (Fig. 5E). Conversely, the inhibition of the NF- $\mathrm{KB}$ pathway by Bay11-7082 enhanced the suppressive effects of TNF- $\alpha$ on the viability of both the RPMI2650 and CLS-354 cells (Fig. 5E). However, the complete abrogation of the decrease in viability was noted by the combination of the inhibitors of caspase- 8 with ASK1, JNK, or IRE1 $\alpha$ inhibitors (Fig. 5E). In addition, the combination of caspase- 8 inhibitor together with the knockdown of PERK by its specific siRNA, or the knockdown of Noxa by the corresponding specific siRNA was found to block TNF- $\alpha$ -induced apoptosis (Fig. 5E). Taken together, these data suggest that the TNF- $\alpha$-induced decrease in cell viability is mediated by different pathways, including the FADD-caspase- 8 and TRAF-ASK1-JNK-p53-Noxa axis, while TNF- $\alpha$-induced survival is mediated by the TRAF-NF- $\mathrm{kB}$ axis.

The possible pathways which are implicated in the modulation of TNF- $\alpha$-induced opposing signals. Based on the outcomes of this study, we proposed model for the possible of TNF- $\alpha$-induced opposing signals in HNSCC cells (Fig. 6). One 
A

\begin{tabular}{|l|c|c|c|c|}
\cline { 2 - 5 } \multicolumn{1}{c|}{} & \multicolumn{4}{c|}{ CLS-354 } \\
\hline TNF-a (10 ng/ml) & - & + & + & - \\
\hline Scramble & + & - & + & - \\
\hline siRNA/Noxa & - & + & - & + \\
\hline \multicolumn{1}{|c|}{ Noxa $\rightarrow$} \\
Actin $\rightarrow$
\end{tabular}

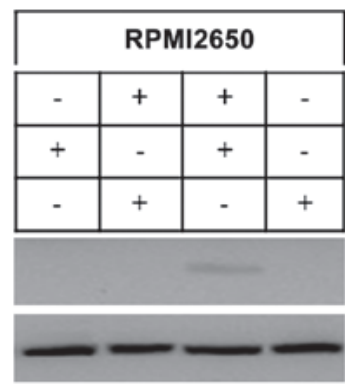

B

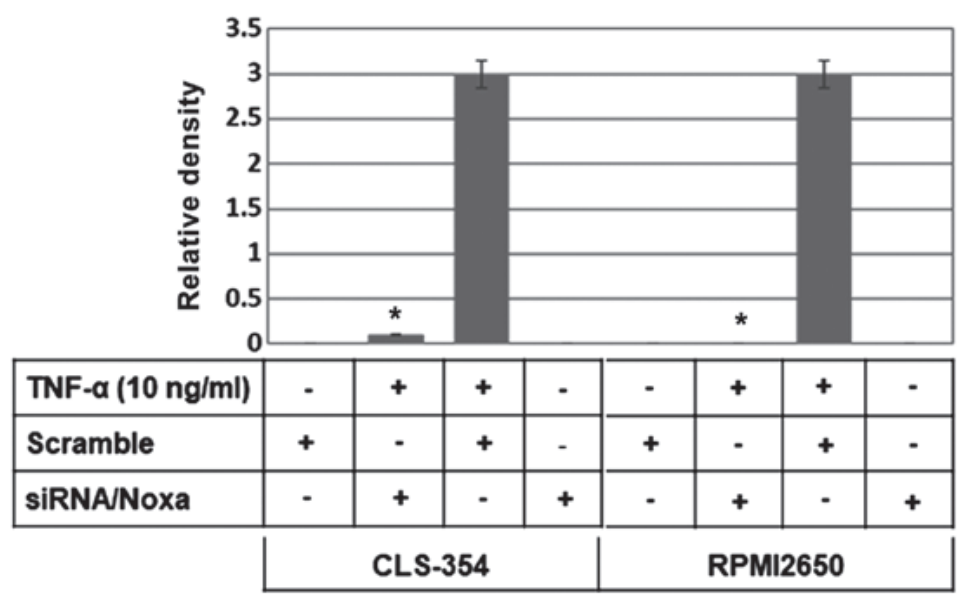

C
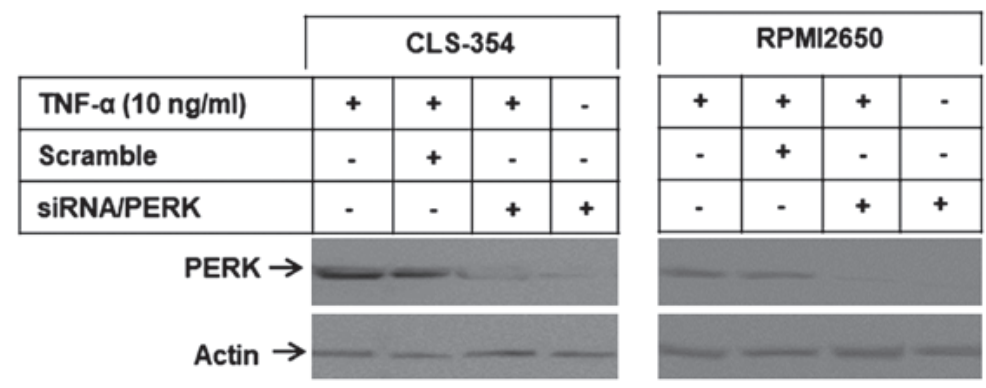

D

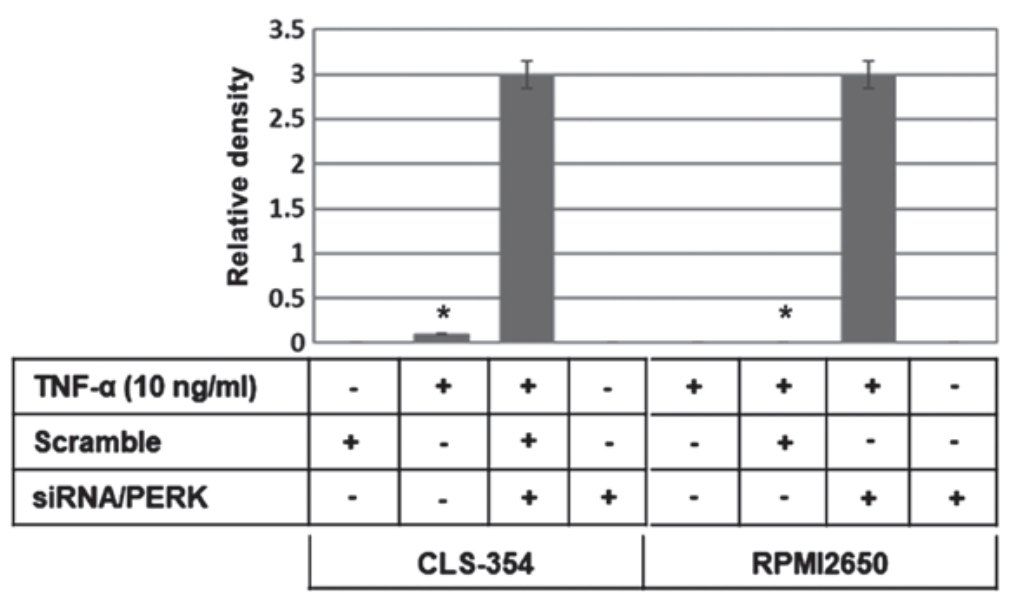

Figure 5. (A) Western blot analysis demonstrating the knockdown of Noxa protein by its specific siRNA (si/Noxa) in CLS-354 and RPMI2650 cells treated with TNF- $\alpha(10 \mathrm{ng} / \mathrm{ml})$. (B) Analyses of band intensity on films are presented as the relative ratio of reduced Noxa to actin. Bars represent the means \pm SD $(\mathrm{n}=3)$. ${ }^{*} \mathrm{P}<0.05$ vs. control. (C) Western blot analysis demonstrating the knockdown of PERK protein by its specific siRNA (si/PERK). Actin was used as an internal control for loading and transfer. (D) Analyses of band intensity on films are presented as the relative ratio of reduced PERK expression to actin. Bars represent the means $\pm \mathrm{SD}(\mathrm{n}=3)$. ${ }^{*} \mathrm{P}<0.05$ vs. control. 


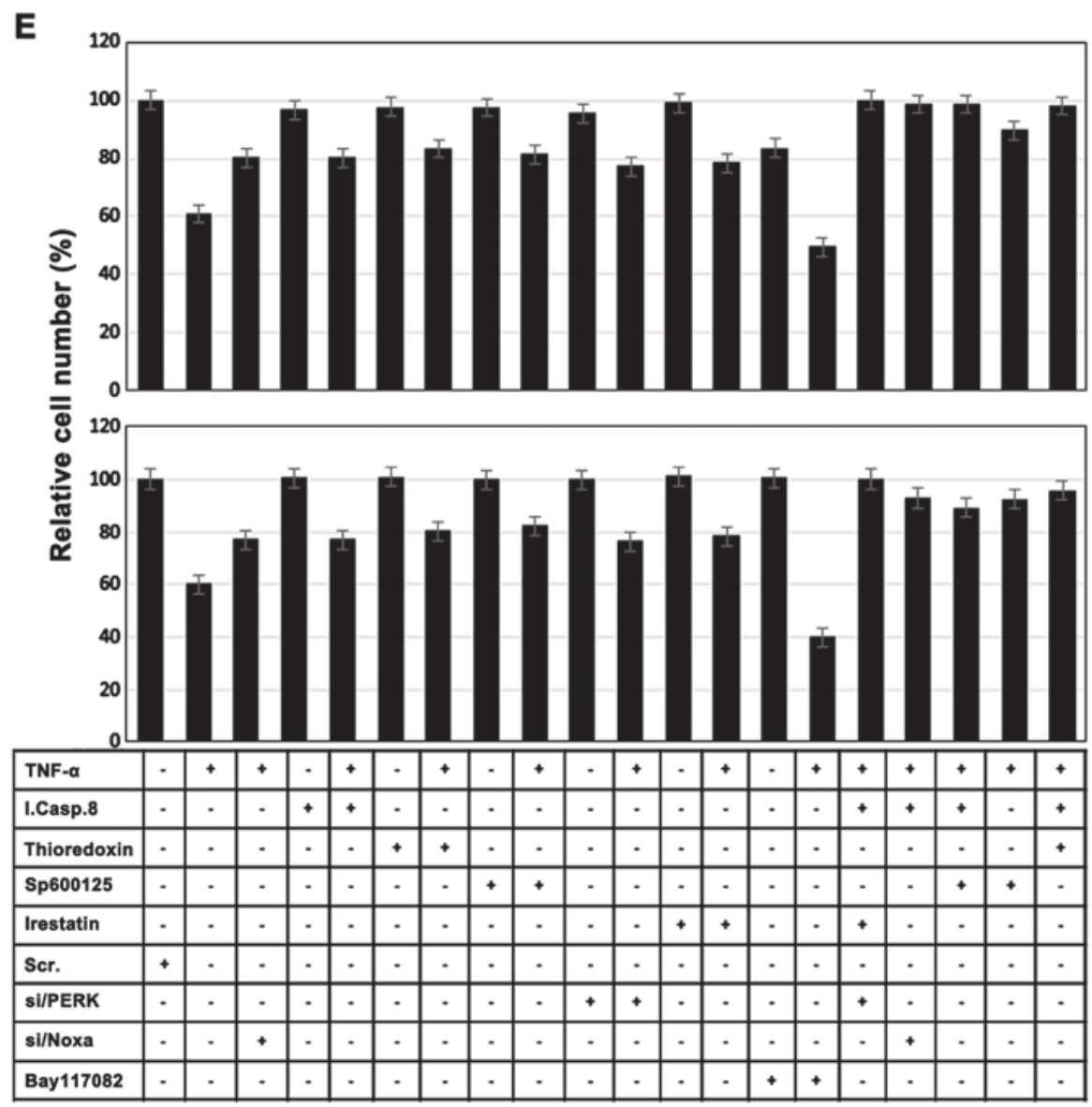

Figure 5. Continued. (E) MTT assay demonstrating the inhibition of TNF- $\alpha$-induced cell death of RPMI2650 (upper panel) and CLS-345 (lower panel) via inhibitors of caspase-8 (I.Casp.8, $20 \mu \mathrm{M}$ ), ASK1 (thioredoxin, $1 \mathrm{nM}$ ), JNK (SP600125, $10 \mu \mathrm{M}$ ), IRE1 $\alpha$ (Irestatin, $25 \mu \mathrm{M}$ ), or by the knockdown of PERK by its specific siRNA (si/PERK). The complete abrogation of the TNF- $\alpha$-induced cell death of head and neck squamous cell carcinoma (HNSCC) cell lines was noted by the knockdown of Noxa by its specific siRNA (si/Noxa) or the combination of ASK1 and caspase-8 inhibitors. Pretreatment of the cells with NF- $\mathrm{kB}$ inhibitor (Bay11-7982, $5 \mu \mathrm{M}$ ) promoted TNF- $\alpha$-induced cell death as evidenced by MTT assay. Data are presented as the means $\pm \mathrm{SD}$ (n=3) performed in quadruplicate.

of these signals is associated with cell death/apoptosis and the other with cell survival. TNF- $\alpha$-induced apoptosis is mediated via the FADD-caspase-8 and TRAF2-ASK-JNK-p53-Noxa axes, while TNF- $\alpha$-induced cell survival is mediated via the TRAF2-NF- $\kappa \mathrm{B}$ axis. The inhibition of the NF- $\kappa \mathrm{B}$ pathway is expected to be a feasible option with which to improve the killing efficiency and to minimize the systemic toxicity of TNF- $\alpha$ in HNSCCs.

\section{Discussion}

In the present study, we demonstrated the molecular mechanisms through which TNF- $\alpha$ induces opposing signals in HNSCC cells. One of these signals leads to cell death and the other leads to cell survival. The TNF- $\alpha$ induced apoptosis of HNSCC cell lines is mediated by extrinsic and intrinsic-dependent mechanisms. The extrinsic apoptotic signal is modulated via the following: i) the FADDmediated activation of caspase- 8 , which in turn, triggers the activation of caspase-3, leading to PARP cleavage and subsequent apoptosis; and ii) the activation of the TRAF2ASK1-JNK-p53-Noxa axis, leading to ER stress-dependent apoptosis. The intrinsic apoptotic signal is mediated via the activation of the TRAF-2-ASK-JNK-p53-Noxa axis, leading to mitochondrial dysregulation-dependent apoptosis. The observed mitochondrial dysregulation and ER stress are the consequences of the subcellular localization of Noxa protein to both mitochondria and ER, respectively.

TNF- $\alpha$ is able to trigger opposing signals in normal and tumor cells; however, the imbalance between survival and apoptotic signals determines whether the cell will survive or die (25-27). In some cell types TNF- $\alpha$ can activate $N F-\kappa B$, leading to cell survival, while in other cell types TNF- $\alpha$ can trigger cell death (15).

In the present study, the induction of opposing signals was noted following the exposure of HNSCC cells to TNF- $\alpha$. The apoptotic signal was mediated by FADD-caspase- 8 and the TRAF2-ASK1-JNK axis, while the survival signal was mediated via the TRAF2-NF- $\kappa$ B axis.

As shown by our data, the TNF- $\alpha$-induced activation of the NF- $\kappa$ B pathway was involved in the inhibition of TNF- $\alpha-$ induced apoptosis. The TNF- $\alpha$-induced activation of the NF- $\kappa$ B pathway was involved in the inhibition of TNF- $\alpha$-induced apoptosis, since the inhibition of the NF- $\kappa \mathrm{B}$ pathway was found to enhance the TNF- $\alpha$-induced apoptosis of HNSCC cells.

The binding of TNF- $\alpha$ to tumor necrosis factor receptor 1 (TNFR1) has been shown to trigger opposing biological responses, leading to cell survival via the $N F-\kappa B$ pathway and cell death via the FADD-caspase- 8 pathway (28-30). The FADD-caspase 8 and TRADD/TRAF2-ASK1-JNK pathways 


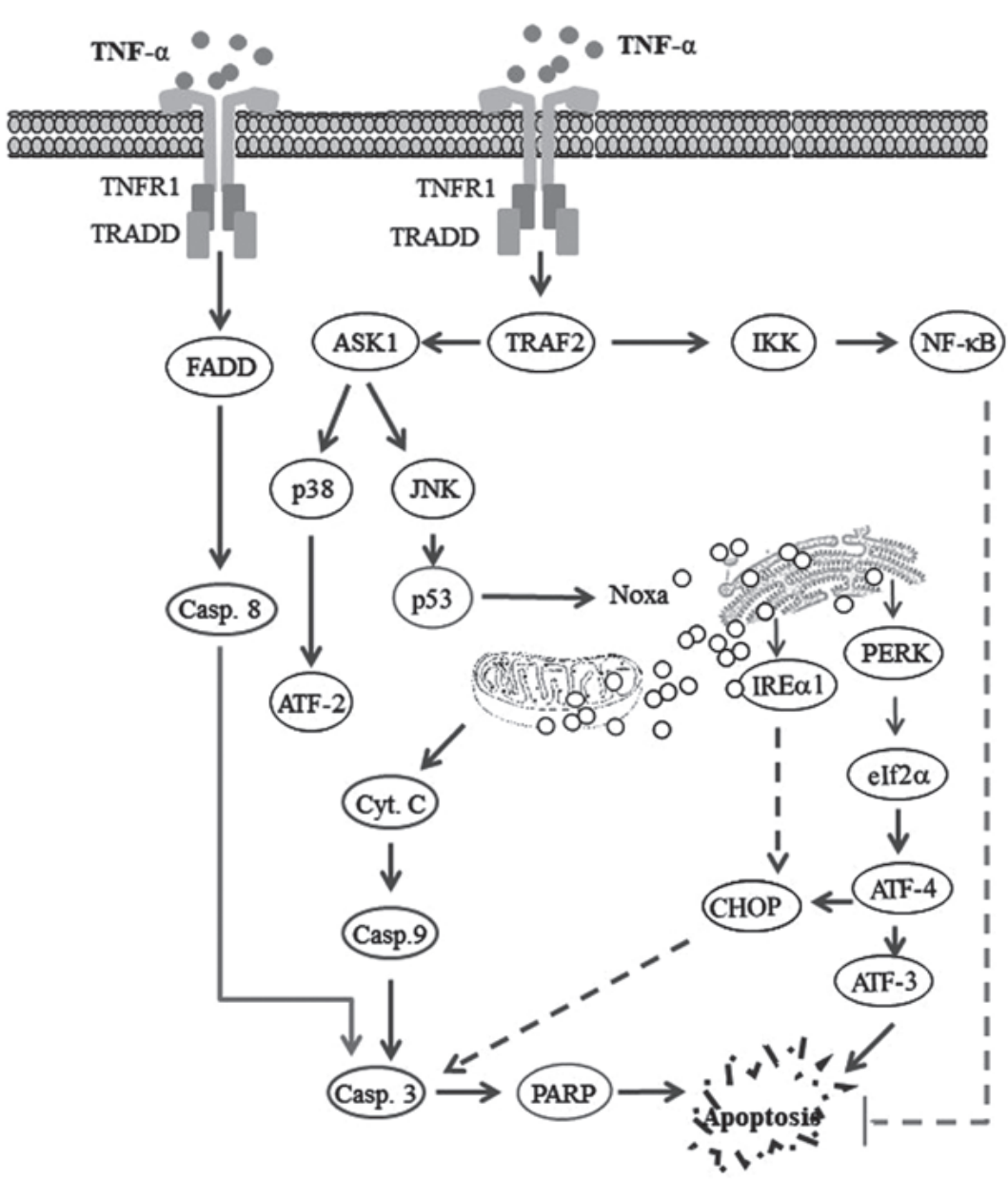

Figure 6. Proposed model for the TNF- $\alpha$-induced apoptosis of head and neck squamous cell carcinoma (HNSCC) cells. The activation of tumor necrosis factor receptor1 (TNFR1) by tumor necrosis factor- $\alpha$ (TNF- $\alpha$ ) triggers opposing biological signals. One of these signals drives the processes of cell survival via a TRAF2-IKK-NF- $\mathrm{B}$ pathway-dependent mechanism, while the other signal drives mitochondrial and non-mitochondrial-dependent cell death via TRAF2-ASK1 and FADD-caspase- 8 mediated pathways. Thus, the TNF- $\alpha$-induced activation of NF- $\kappa B$ pathway results in the transcriptional activation of anti-apoptotic genes, leading to the inhibition of apoptosis. By contrast, the TNF- $\alpha$-induced activation of the FADD-caspase- 8 pathway results in the cleavage of caspase-3 and PARP, leading to apoptosis. TNF- $\alpha$-induced TRAF2-ASK1-JNK activation results in the activation of ASK1, the subsequent activation of the kinase JNK and p38, and leads to the enhancement of the DNA-binding activity of the transcription factors p53 and ATF-2, respectively. The transcription factor p53 then enhances the expression of the pro-apoptotic protein Noxa, whose localization to mitochondria and endoplasmic reticulum (ER) results in mitochondrial dysregulation and ER stress. Mitochondrial dysregulation results in the release of cytochrome $c$ (Cyt.c), which in turn leads to the cleavage of caspase-9, caspase-3 and PARP, and finally apoptosis. ER stress results in the activation of PERK, which in turn mediates the phosphorylation of IRE1 $\alpha$, activating the transcription factor ATF-4 which triggers the activation of ATF-3 and the expression of CHOP, ultimately leading to the induction of apoptosis.

are involved in the modulation of TNF- $\alpha$-induced apoptotic signals (31-33), whereas the TRADD/TRAF2-NF- $\mathrm{kB}$ pathway mediates TNF- $\alpha$-induced survival signals $(34,35)$.

The role of ASK1 in the modulation of apoptotic signals induced by different apoptotic stimuli has been reported in several studies (36-38). ASK1 is a member of the MAPK family, as well as an upstream activator of the JNK and p38-MAPK signaling cascades (39). Our data revealed that the activation of ASK1 by TNF- $\alpha$ via TRAF2 resulted in the activation of JNK, and subsequently the DNA-binding activities of the transcription factor p53 that play an essential role in the transcriptional regulation of the pro-apoptotic mediator Noxa. Our findings demonstrate that the localization of Noxa protein to both the mitochondria and ER is essential to trigger mitochondrial dysregulation and ER stress. Noxa-induced mitochondrial dysregulation is characterized by the loss of $\Delta \psi \mathrm{m}$, cytochrome $c$ release, and the cleavage of caspase-3, caspase-9 and PARP. Noxa-induced ER stress is associated with the activation of both the PERK and IRE1 $\alpha$ pathways, including the downstream activation of eIf $2 \alpha$ and ATF-3, ATF-4 induction and CHOP expression. However, the role of mitochondrial-dependent $(19,40)$ and ER stress-dependent (19) pathways in the modulation of the apoptosis of HNSCC cells has not been reported to date, at least to the best of our knowledge.

TRAF2 has been recognized for its crucial role in the regulation of the downstream signaling pathways that are implicated in the modulation of TNF- $\alpha$ signals, leading to either cell growth or cell death. The induction of apoptosis by TNF- $\alpha$ is mediated by TRAF2 via the activation of the ASK1-JNK pathway, while TNF- $\alpha$-induced cell growth is mediated via the TRAF2-IKK-NF- $\kappa B$ pathway. The lack of TRAF2 results in the suppression of the TNF- $\alpha$-induced activation of the ASK1-JNK and NF-кB pathways $(41,42)$.

In the present study, we demonstrated that the TNF- $\alpha$ induced activation of NF- $\mathrm{KB}$ attenuated TNF- $\alpha$-induced apoptosis, while the inhibition of the NF- $\mathrm{KB}$ pathway was associated with the enhancement of TNF- $\alpha$-induced 
apoptosis. By contrast, the TNF- $\alpha$-induced activation of the ASK1-JNK pathway is responsible for the enhancement of the DNA-binding activity of the transcription factor p53, leading to the transcriptional activation of the pro-apoptotic gene Noxa. As consequence, the development of a therapeutic strategy based on the combination of TNF- $\alpha$ and the inhibitor of NF- $\kappa$ B may be a good option for the treatment of HNSCC.

In this study, TNF- $\alpha$-induced opposite signals triggered both cell death through extrinsic and intrinsic apoptotic pathways, and cell survival through the $\mathrm{NF}-\kappa \mathrm{B}$ pathway. The extrinsic apoptotic pathway is mediated by TRADD/FADD/caspase-8, while the activation the intrinsic apoptotic pathway the consequence of TRADD/TRAF axis-induced ASK1 activation. The activation of ASK1 results in the activation of JNK that, in turn, enhances the DNA binding activity of the transcription factors such as p53 to promote transcription and subsequently the translation of the apoptotic mediator Noxa. As consequence, the binding of Noxa protein to both the mitochondria and ER results in the induction of mitochondrial dysregulation and ER stress-dependent apoptotic pathways, while the TNF- $\alpha$-induced survival/inhibition of apoptosis is mediated by the TRADD/TRAF2/IKK/NF- $\kappa$ B axis.

In a previous study by our group [El Jamal et al (19)], we demonstrated that the production of IFN $\gamma$ by immune effector cells as a consequence of tumor-induced immune response. IFN $\gamma$ triggers the activation of the corresponding receptor that in turn activates the JAK1/STAT1 pathway to enhance the DNA-binding activity of the transcription factor, interferon regulatory factor-1 (IRF-1) to enhance the transcription of the indolamine-2,3-dioxygenase (IDO) that functions as inhibitor of the anti-oxidant protein heme oxygenase-1 (HO-1). As consequence, the uncontrolled tumor oxidation processes increases the accumulation of the reactive oxygen species (ROS), leading to the induction cellular stress- dependent mechanisms in the form of ASK1 activation. Activated ASK1 then is able to trigger the activation of different pathways, leading to the enhancement of the DNA-binding activity of transcription factors $\mathrm{NF}-\kappa \mathrm{B}, \mathrm{p} 53$ and AP-1 that are essential for the transcriptional activation of Noxa gene. The binding of Noxa protein to both mitochondria and ER results in the induction of mitochondrial dysregulation and ER stress leading the induction of pro-and anti-apoptotic-dependent pathways.

Although the role of Noxa protein is specific for both studies, Noxa protein in the study by El Jamal et al (19) is the main mediator of IFN $\gamma$-induced apoptosis of HNSCC-derived cell lines. While in the present study, Noxa protein contributes in part in the modulation of TNF- $\alpha$-induced apoptosis.

It should be noted herein that, although there are certain similarities, our previous study [El Jamal et al (19)] and the present study, do have some differences. The present study addresses the opposing signaling that can be induced as consequence for the treatment of HNSCC with TNF- $\alpha$ with the aim of reducing the adverse effects of TNF- $\alpha$ as an anticancer agent. In this study, the TNF- $\alpha$-induced opposing signals trigger both cell death through extrinsic and intrinsic apoptotic pathways, and the survival pathway through $\mathrm{NF}-\kappa \mathrm{B}$. The extrinsic apoptotic pathway is mediated by TRADD/FADD/caspase- 8 , while the activation the intrinsic apoptotic pathway is the consequence of TRADD/TRAF axis-induced ASK1 activation. The activation of ASK1 results in the activation of JNK that has the ability to enhance the DNA binding activity of the transcription factors, such as p53 for the transcriptional activation of the apoptotic mediator, Noxa. As consequence, the binding of Noxa protein to both the mitochondria and ER results in the induction of mitochondrial dysregulation and ER stress-dependent apoptotic pathways, while the TNF- $\alpha$-induced survival/inhibition of apoptosis is mediated by the TRADD/TRAF2/IKK/NF- $\mathrm{B}$ axis.

In conclusion, based on our findings, we proposed a model for the TNF- $\alpha$-induced effects on HNSCC cells (Fig. 6). Our model outlines the possible pathways involved in the modulation of TNF- $\alpha$-induced opposing signals in HNSCC cells. One of these signals is associated with cell death/apoptosis and the other is associated with cell survival. TNF- $\alpha$-induced apoptosis is mediated via the FADD-caspase- 8 and TRAF2-ASK-JNKp53-Noxa axes, while TNF- $\alpha$-induced cell survival is mediated via the TRAF2-NF- $\kappa$ B axis. The inhibition of the $\mathrm{NF}-\kappa \mathrm{B}$ pathway is expected to be a feasible option with which to improve the killing efficiency and to minimize the systemic toxicity of TNF- $\alpha$ in HNSCCs. Thus, the confirmation of our in vitro findings in a preclinical model may help in the development of a clinically relevant protocol for the treatment of HNSCC with TNF- $\alpha$.

\section{Acknowledgements}

The authors would like to thank Miss Sarah-Lilly Hassan for providing technical assistance.

\section{Funding}

This study was supported by grants from the German Research Foundation (HA5081/3-1), from L'Alsace contre le cancer, France, German cancer research Foundation (10-2202-Ha1) to MH.

\section{Availability of data and materials}

The analyzed datasets generated during the study are available from the corresponding author on reasonable request.

\section{Authors' contributions}

DS, ER and SYH carried out the cell culture, MTT assay, flow cytometry analysis, western blot analysis and immunofluorescence staining experiments; TWF performed the immunofluorescence experiment, and was involved in the flow cytometric analysis, as well as in manuscript editing; DS, SS and $\mathrm{MH}$ conceived the study design and designed the experiments; DS and MH carried out EMSA; SS, RA, PF, YH, RUW, $\mathrm{EK}, \mathrm{MM}$ and $\mathrm{MH}$ contributed to the design of the study, as well as to the analysis and discussion of the results, and the writing of the manuscript. All authors read and approved the manuscript.

\section{Ethics approval and consent to participate}

Not applicable.

\section{Consent for publication}

Not applicable. 


\section{Competing interests}

The authors declare that they have no competing interests.

\section{References}

1. Aderhold C, Faber A, Umbreit C, Birk R, Weiss C, Sommer JU, Hörmann $\mathrm{K}$ and Schultz JD: Targeting mTOR and AREG with everolimus, sunitinib and sorafenib in HPV-positive and -negative SCC. Anticancer Res 35: 1951-1959, 2015.

2. Pauzie A, Gavid M, Dumollard JM, Timoshenko A, Peoc'h M and Prades JM: Infracentimetric cervical lymph node metastasis in head and neck squamous cell carcinoma: Incidence and prognostic value. Eur Ann Otorhinolaryngol Head Neck Dis 133 307-311, 2016.

3. Zumsteg ZS, Cook-Wiens G, Yoshida E, Shiao SL, Lee NY, Mita A, Jeon C, Goodman MT and Ho AS: Incidence of Oropharyngeal Cancer Among Elderly Patients in the United States. JAMA Oncol 2: 1617-1623, 2016.

4. Kurzweg T, Kimmeyer J, Knecht R, Hoffmann TK, Busch CJ, Lörincz BB, Schuler PJ and Laban S: Curative treatment of head and neck squamous cell carcinoma: Organ preservation strategies in clinical routine in German-speaking countries. HNO 64 501-507, 2016.

5. Braig F, Kriegs M, Voigtlaender M, Habel B, Grob T, Biskup K, Blanchard V, Sack M, Thalhammer A, Ben Batalla I, Braren I, Laban S, et al: Cetuximab Resistance in Head and Neck Cancer Is Mediated by EGFR-K521 Polymorphism. Cancer Res 77: $1188-1199,2017$

6. Baetu TM and Hiscott J: On the TRAIL to apoptosis. Cytokine Growth Factor Rev 13: 199-207, 2002.

7. Harry GJ, Lefebvre d'Hellencourt C, McPherson CA, Funk JA, Aoyama M and Wine RN: Tumor necrosis factor p55 and p75 receptors are involved in chemical-induced apoptosis of dentate granule neurons. J Neurochem 106: 281-298, 2008.

8. Fiers W: Tumor necrosis factor. Characterization at the molecular, cellular and in vivo level. FEBS Lett 285: 199-212, 1991.

9. Elkady AI, Hussein RA and El-Assouli SM: Mechanism of action of Nigella sativa on human colon cancer cells: The suppression of AP- 1 and NF- $\mathrm{kB}$ transcription factors and the induction of cytoprotective genes. Asian Pac J Cancer Prev 16: 7943-7957, 2015.

10. Moujalled DM, Cook WD, Lluis JM, Khan NR, Ahmed AU, Callus BA and Vaux DL: In mouse embryonic fibroblasts, neither caspase- 8 nor cellular FLICE-inhibitory protein (FLIP) is necessary for TNF to activate NF- $\mathrm{KB}$, but caspase- 8 is required for TNF to cause cell death, and induction of FLIP by NF-kB is required to prevent it. Cell Death Differ 19: 808-815, 2012

11. Van Hauwermeiren F, Vandenbroucke RE, Grine L, Lodens S, Van Wonterghem E, De Rycke R, De Geest N, Hassan B and Libert C: TNFR1-induced lethal inflammation is mediated by goblet and Paneth cell dysfunction. Mucosal Immunol 8 : 828-840, 2015.

12. Lans TE, Bartlett DL, Libutti SK, Gnant MF, Liewehr DJ, Venzon DJ, Turner EM and Alexander HR: Role of tumor necrosis factor on toxicity and cytokine production after isolated hepatic perfusion. Clin Cancer Res 7: 784-790, 2001.

13. Frączek N, Bronisz I, Pietryka M, Kępińska D, Strzała P, Mielnicka K, Korga A and Dudka J: An outline of main factors of drug resistance influencing cancer therapy. J Chemother 28 : 457-464, 2016

14. Hassan M, Feyen O and Grinstein E: Fas-induced apoptosis of renal cell carcinoma is mediated by apoptosis signal-regulating kinase 1 via mitochondrial damage-dependent caspase- 8 activation. Cell Oncol 31: 437-456, 2009.

15. Cetindere T, Nambiar S, Santourlidis S, Essmann F and Hassan M: Induction of indoleamine 2,3-dioxygenase by death receptor activation contributes to apoptosis of melanoma cells via mitochondrial damage-dependent ROS accumulation. Cell Signal 22 197-211, 2010.

16. Rauert H, Stühmer T, Bargou R, Wajant H and Siegmund D: TNFR1 and TNFR2 regulate the extrinsic apoptotic pathway in myeloma cells by multiple mechanisms. Cell Death Dis 2: e194, 2011.

17. Ridinger-Saison M, Evanno E, Gallais I, Rimmelé P, Selimoglu-Buet D, Sapharikas E, Moreau-Gachelin F and Guillouf C: Epigenetic silencing of Bim transcription by Spi-1/PU.1 promotes apoptosis resistance in leukaemia. Cell Death Differ 20: $1268-1278,2013$.
18. Chung SK, Lee MG, Ryu BK, Lee JH, Han J, Byun DS, Chae KS, Lee KY, Jang JY, Kim HJ, et al: Frequent alteration of XAF1 in human colorectal cancers: Implication for tumor cell resistance to apoptotic stresses. Gastroenterology 132: 2459-2477, 2007.

19. El Jamal SM, Taylor EB, Abd Elmageed ZY, Alamodi AA, Selimovic D, Alkhateeb A, Hannig M, Hassan SY, Santourlidis S, Friedlander PL, et al: Interferon gamma-induced apoptosis of head and neck squamous cell carcinoma is connected to indoleamine2,3-dioxygenase via mitochondrial and ER stress-associated pathways. Cell Div 11: 11, 2016

20. El-Khattouti A, Selimovic D, Hannig M, Taylor EB, Abd Elmageed ZY, Hassan SY, Haikel Y, Kandil E, Leverkus M, Brodell RT, et al: Imiquimod-induced apoptosis of melanoma cells is mediated by ER stress-dependent Noxa induction and enhanced by NF- $\kappa$ B inhibition. J Cell Mol Med 20: 266-286, 2016.

21. Hassan M, Alaoui A, Feyen O, Mirmohammadsadegh A, Essmann F, Tannapfel A, Gulbins E, Schulze-Osthoff K and Hengge UR: The BH3-only member Noxa causes apoptosis in melanoma cells by multiple pathways. Oncogene 27: 4557-4568, 2008.

22. Selimovic D, Ahmad M, El-Khattouti A, Hannig M, Haïkel Y and Hassan M: Apoptosis-related protein-2 triggers melanoma cell death by a mechanism including both endoplasmic reticulum stress and mitochondrial dysregulation. Carcinogenesis 32: 1268-1278, 2011.

23. El-Khattouti A, Sheehan NT, Monico J, Drummond HA, Haikel Y, Brodell RT, Megahed M and Hassan M: CD133+ melanoma subpopulation acquired resistance to caffeic acid phenethyl ester-induced apoptosis is attributed to the elevated expression of ABCB5: Significance for melanoma treatment. Cancer Lett 357: 83-104, 2015.

24. Selimovic D, Badura HE, El-Khattouti A, Soell M, Porzig BB, Spernger A, Ghanjati F, Santourlidis S, Haikel Y and Hassan M: Vinblastine-induced apoptosis of melanoma cells is mediated by Ras homologous A protein (Rho A) via mitochondrial and nonmitochondrial-dependent mechanisms. Apoptosis 18: 980-997, 2013.

25. Lo SZ, Steer JH and Joyce DA: Tumor necrosis factor-alpha promotes survival in methotrexate-exposed macrophages by an NF-kappaB-dependent pathway. Arthritis Res Ther 13: R24, 2011.

26. Benedetti G, Ramaiahgaris S, Herpers B, van de Water B, Price LS and de Graauw M: A screen for apoptotic synergism between clinical relevant nephrotoxicant and the cytokine TNF- $\alpha$. Toxicol In Vitro 27: 2264-2272, 2013.

27. Gozzelino R, Sole C, Llecha N, Segura MF, Moubarak RS, Iglesias-Guimarais V, Perez-Garcia MJ, Reix S, Zhang J, Badiola N, et al: BCL-XL regulates TNF-alpha-mediated cell death independently of NF-kappaB, FLIP and IAPs. Cell Res 18: 1020-1036, 2008

28. Kitagawa M, Shiozaki A, Ichikawa D, Nakashima S, Kosuga T, Konishi H, Komatsu S, Fujiwara H, Okamoto K and Otsuji E: Tumor necrosis factor- $\alpha$-induced apoptosis of gastric cancer MKN28 cells: Accelerated degradation of the inhibitor of apoptosis family members. Arch Biochem Biophys 566: 43-48, 2015.

29. Kim H and Ray R: Evasion of TNF- $\alpha$-mediated apoptosis by hepatitis C virus. Methods Mol Biol 1155: 125-132, 2014.

30. Liu L, Yim H, Choi JH, Kim ST, Jin Y and Lee SK: ATM kinase promotes both caspase- 8 and caspase-9 activation during TNF- $\alpha$-induced apoptosis of HeLa cells. FEBS Lett 588: 929-935, 2014.

31. Zheng M, Wu Z, Wu A, Huang Z, He N and Xie X: MiR-145 promotes TNF- $\alpha$-induced apoptosis by facilitating the formation of RIP1-FADDcaspase- 8 complex in triple-negative breast cancer. Tumour Biol 37: 8599-8607, 2016.

32. Fukuyo Y, Kitamura T, Inoue M, Horikoshi NT, Higashikubo R, Hunt CR, Usheva A and Horikoshi N: Phosphorylationdependent Lys63-linked polyubiquitination of Daxx is essential for sustained TNF-\{alpha\}-induced ASK1 activation. Cancer Res 69: 7512-7517, 2009.

33. Min W, Lin Y, Tang S, Yu L, Zhang H, Wan T, Luhn T, Fu H and Chen H: AIP1 recruits phosphatase PP2A to ASK1 in tumor necrosis factor-induced ASK1-JNK activation. Circ Res 102: 840-848, 2008

34. Jackson-Bernitsas DG, Ichikawa H, Takada Y, Myers JN, Lin XL, Darnay BG. Chaturvedi MM and Aggarwal BB: Evidence that TNF-TNFR1-TRADD-TRAF2-RIP-TAK1-IKK pathway mediates constitutive NF-kappaB activation and proliferation in human head and neck squamous cell carcinoma. Oncogene 26: 1385-1397, 2007 
35. Zhang J, Liang Y, Lin Y, Liu Y, YouYou and Yin W: IRE1 $\alpha$-TRAF2-ASK1 pathway is involved in CSTMP-induced apoptosis and ER stress in human non-small cell lung cancer A549 cells. Biomed Pharmacother 82: 281-289, 2016.

36. World C, Spindel ON and Berk BC: Thioredoxin-interacting protein mediates TRX1 translocation to the plasma membrane in response to tumor necrosis factor- $\alpha$ : A key mechanism for vascular endothelial growth factor receptor-2 transactivation by reactive oxygen species. Arterioscler Thromb Vasc Biol 31: 1890-1897, 2011

37. Guo Y, Lin D, Zhang M, Zhang X, Li Y, Yang R, Lu Y, Jin X, Yang M, Wang M, et al: CLDN6-induced apoptosis via regulating ASK1-p38/JNK signaling in breast cancer MCF-7 cells. Int J Oncol 48: 2435-2444, 2016.

38. Bieerkehazhi S, Chen Z, Zhao Y, Yu Y, Zhang H, Vasudevan SA Woodfield SE, Tao L, Yi JS, Muscal JA, et al: Novel Src/Abl tyrosine kinase inhibitor bosutinib suppresses neuroblastoma growth via inhibiting Src/Abl signaling. Oncotarget 8: 1469-1480, 2017.
39. Mantzaris MD, Bellou S, Skiada V, Kitsati N, Fotsis T and Galaris D: Intracellular labile iron determines $\mathrm{H} 2 \mathrm{O} 2$-induced apoptotic signaling via sustained activation of ASK1/JNK-p38 axis. Free Radic Biol Med 97: 454-465, 2016.

40. Zhai X, Yang Y, Wan J, Zhu R and Wu Y: Inhibition of LDH-A by oxamate induces $\mathrm{G} 2 / \mathrm{M}$ arrest, apoptosis and increases radiosensitivity in nasopharyngeal carcinoma cells. Oncol Rep 30: 2983-2991, 2013

41. Nishitoh H, Saitoh M, Mochida Y, Takeda K, Nakano H, Rothe M, Miyazono K and Ichijo H: ASK1 is essential for JNK/SAPK activation by TRAF2. Mol Cell 2: 389-395, 1998.

42. Cabal-Hierro L, Rodríguez M, Artime N, Iglesias J, Ugarte L, Prado MA and Lazo PS: TRAF-mediated modulation of NF- $\kappa \mathrm{B}$ and JNK activation by TNFR2. Cell Signal 26: 2658-2666, 2014. 